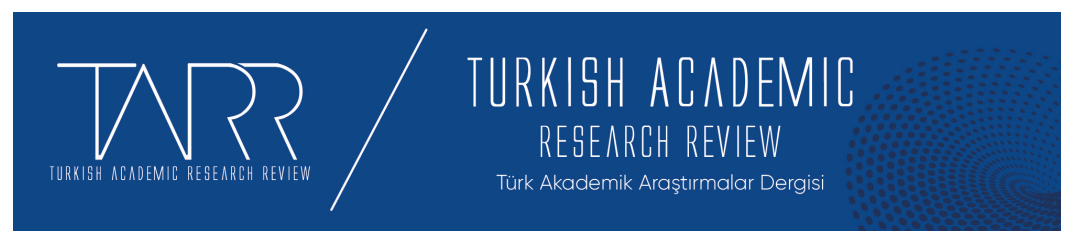

e-ISSN: 2602-2923 Yil/Year: $2021 \quad$ Cilt/Volume: 6 Sayı/Issue: 1

\title{
Cezaî Sorumluluk Bağlamında İkrah ve Hukuki Sonuçları
}

Benefit and its Legal Consequences in the Context of Criminal Liability

\section{Yaşar YİĞİT}

Doç. Dr., Ankara Yıldırım Beyazıt Üniversitesi İslami İlimler Fakültesi, İslam Hukuku Anabilim Dalı/Associate Professor, University of Ankara Yıldırım Beyazıt, Faculty of Islamic Studies Department of Islamic Law, Ankara/Turkey, yyigit@ybu.edu.tr/ dryasar66@hotmail.com/,Orcid ID: 0000-0002-2152-524X

\begin{tabular}{r|l} 
Makale Bilgisi & Article Information \\
Makale Türü - Article Type & Araştırma Makalesi / Research Article \\
Geliş Tarihi - Date Received & 30 Aralık / December 2020 \\
Kabul Tarihi - Date Accepted & 22 Mart / March 2021 \\
Yayın Tarihi - Date Published & 25 Mart / March 2021 \\
Yayın Sezonu & Ocak - Şubat - Mart \\
Pub Date Season & January - February - March
\end{tabular}

Atıf / Cite as: Yiğit, Yaşar, Cezaî Sorumluluk Bağlamında İkrah ve Hukuki Sonuçlari/Benefit and its Legal Consequences in the Context of Criminal Liability. tarr: Turkish Academic Research Review, 6 (1), 116-144. doi: 10.30622 tarr.850211.

Intihal / Plagiarism: Bu makale, en az iki hakem tarafından incelenmiş ve intihal içermediği teyit edilmiştir. / This article has been reviewed by at least two referees and confirmed to include no plagiarism. https://dergipark.org.tr/tr/pub/tarr

Copyright $(\odot$ Published by Mehmet ŞAHIN Since 2016- Akdeniz University, Faculty of Theology, Antalya, 07058 Turkey. All rights reserved.

Turkish Academic Research Review - Türk Akademik Araştırmalar Dergisi 


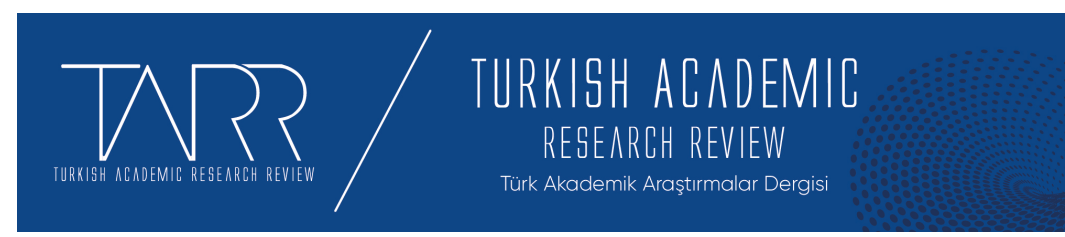

e-ISSN: 2602-2923 Yıl/Year: $2021 \quad$ Cilt/Volume: 6 Sayı/Issue: 1

\section{Cezaî Sorumluluk Bağlamında İkrah Ve Hukuki Sonuçları}

\section{Yaşar YİĞíT}

Özet

İkrah; tehdit ettiği şeyi yapmaya muktedir kabiliyetteki bir şahsın, bir başka kişiyi, korkutmak ya da tehdit suretiyle kendi hâline bırakıldığında yapmaya rıza göstermeyeceği ve tercih etmeyeceği bir fiili işlemeye ya da bir sözü söylemeye sevk edilmesidir. İslam hukukçuları ikrahı genelde tehdit unsurunun ağırlığını merkeze almak suretiyle bir ayrıma tabi tutmuşlardır. Özellikle Hanefiler, hukuki sonuçları açısından ikrahı, mülcî/tam, gayr-1 mülcî/eksik ve manevî/psikolojik ikrah şeklinde bir ayrıma tabi tutmuşlardır. Tam ikrahta tehdit, ikraha konu olan kişinin can ve vücut tamlığına yöneliktir. Eksik ikrahta ise, kişinin can ve vücut tamlığına yönelik bir tehdit bulunmamakla beraber dövme, hapsetme, dinen haram kabul edilen bazı yiyecekleri yeme, içme gibi tehdit söz konusudur. Cezaî sorumluluk, temyiz gücüne sahip bir bireyin serbest iradesiyle başkalarına karşı sözlü ve fiili olarak suç kapsamında değerlendirilen haksız saldırıda bulunması neticesinde kanunda/hukukta öngörülen cezaya katlanma sorumluluğudur. Öldürme, vücut tamlığına karșı bir eylemde bulunmak gibi, hiçbir şekilde işlenmesi mubah hale gelmeyen fiillerde ikrahın varlığı bu tür fiillerin hukuki sonuçlarını etkilemez. İkrahın etkisiyle mubah hale gelen eylemler, cezaî sorumluluğu da kaldırmaktadır. Zira bu tür fiillerde cezaî sorumluluğun hukuka aykırılık ilkesi eksik kalmaktadır.

Anahtar Kelimeler: İslam Ceza Hukuku, İkrah, Cezaî Sorumluluk, İkrah-1 mülcî, Eksik İkrah

\footnotetext{
Benefit and its Legal Consequences in the Context of Criminal Liability Abstract

Ikrah is a coercion or threat exercise of a person capable of doing what he/she threatens upon another person to produce a fear, which causes him/her to undertake an action or utter a word that would not otherwise be shown consent. Islamic jurists generally tend to classify the ikrah into different forms essentially by taking the extent of threat into account. Considering its legal consequences, the Hanafis, in particular, divide the $i \mathrm{krah} /$ duress into three main categories: mulji/compelling or complete; gahyr-i mulji/ not as compelling or incomplete and moral/psychological duress. In case of compelling duress, the threat is directed to the life and body integrity of threatened person. The second type does not create a compelling fear against the life and body integrity of threatened person but does include some actions like beating, imprisonment, or forcing to break religious dietary restrictions. Criminal liability is the responsibility of an individual attained the age of reason (tamyiz) to endure the punishment stipulated in the law for any unjust and illegal attack upon others he/she commits an with free will. For the ever non-permitted actions such as killing or taking an action against bodily integrity, the existence of ikrah does not affect the legal consequences of such actions. Actions that become permissible due to the effect of the ikrah/duress also nullify criminal liability because in such acts, the principle of the illegality in criminal responsibility remains incomplete.
}

Key Words: Islamic Criminal Law, Ikrah/Doctrine of Duress, Criminal Liability, Ikrah-1 Müljî/Compelling Duress or Gahyr-i Mulji/ Incomplete Duress.

Turkish Academic Research Review - Türk Akademik Araştırmalar Dergisi 


\section{Structured Abstract}

Ikrah is a coercion or threat exercise of a person capable of doing what he/she threatens upon another person to produce a fear, which causes him/her to undertake an action or utter a word that would not otherwise be shown consent. Islamic jurists generally tend to classify the ikrah into different forms essentially by taking the extent of threat into account. Although ikrah is considered within the scope of competence failures in Islamic law, it is a situation that is evaluated in the context of causes that break consent or defects of will in works written by contemporary Islamic jurists. Although Islamic jurists make different evaluations regarding the legal consequences of the words and deeds of the muqreh, almost all of them agree that ikrah removes consent. Considering its legal consequences, the Hanafis, in particular, divide the ikrah/duress into three main categories: mulji/compelling or complete; gahyr-i mulji/ not as compelling or incomplete and moral/psychological duress. In case of compelling duress, the threat is directed to the life and body integrity of threatened person. The second type does not create a compelling fear against the life and body integrity of threatened person but does include some actions like beating, imprisonment, or forcing to break religious dietary restrictions. Hanafis, unlike other jurists, stated that both types of ikrah abolished consent whether it is full ikrah or incomplete ikrah, both types of ikrah abolished consent, the old man did not break in the non-immigrant / incomplete ikrah, and in the muljî / full ikrah, it did not disappear. Hanafis are of the opinion that while the ikrah ruins the old man, but does not remove it, the savings of the taxpayer in this scope have legal consequences. Since ikrah revokes the consent of the compelled person, in principle, it is not possible to talk about the criminal responsibility of the criminal. Criminal liability is the responsibility of an individual attained the age of reason (tamyiz) to endure the punishment stipulated in the law for any unjust and illegal attack upon others he/she commits an with free will. For the ever non-permitted actions such as killing or taking an action against bodily integrity, the existence of $i k r a h$ does not affect the legal consequences of such actions. Actions that become permissible due to the effect of the ikrah/duress also nullify criminal liability because in such acts, the principle of the illegality in criminal responsibility remains incomplete. Therefore, since we cannot talk about the existence of these elements under ikrah, it is not possible to mention the criminal responsibility of the criminal due to the crime committed, whether it is in the scope of the hadd, murder or ta'zir. Because the mukreh does not have the consent and will of the caste regarding the outcome. On the other hand, the weight of the ikrah, its possibility of occurrence and its conditions are important factors in determining this responsibility. In determining the effect of the loan on criminal liability, the principle that the damage cannot be eliminated by another damage of the same magnitude and the rule that severe damage will be eliminated by enduring light damage has been effective. Therefore, if the recipient chooses more damage for less damage, he will also be liable in terms of punishment. Therefore, the criminal responsibility of the taxpayer will continue in the offense he will commit against the integrity of his life, property and bodily by compulsion, which is considered as non-immigrant. A person who is under loan is not liable for a penalty if he says the words and acts that legislator/Shari allowed to be committed in case of necessity. Because, in such actions, the element of illegality is eliminated as well as the criminal intent. Mukreh does not become a sinner because of such actions. However, the nature of the words or actions within this scope continues to be a crime. Verbal acts of the Mukreh were also discussed among Islamic jurists. According to the Shafii, Maliki and Hanbali jurists, the word of the forced has no legal value. The words to be made by those who are forced while under loyalty do not bind him. Divorce, sales contract and verbal savings of the forced person are invalid. On the other hand, Hanafis stated that the verbal acts of the mukreh would have legal consequences.

Turkish Academic Research Review - Türk Akademik Araştırmalar Dergisi 


\section{Giriş}

İnsan, yaratılışı ve ihtiyaçları gereği toplum halinde yaşamak durumundadır. Toplum halinde uzlaşı içinde yaşamanın şüphesiz belirli kuralları vardır. Toplumu örgütleyen ve bir arada yaşamalarını sağlayan bu kurallar bütünü niteliğine göre gelenek-görenek, ahlak, din ve hukuk şeklinde bölümlere ayrılmaktadır. Söz konusu kuralların oluşumu tarihsel sürecin birikiminin, insanlık tecrübe ve ufkunun özetidir. Diğer taraftan bahse konu kuralların bir kısmına uyup uymama kişinin tercihine ya da ihtiyarına bırakılmıştır. Bu nitelikteki kuralların ihlal ve ihmali herhangi bir yaptırımı müstelzim değildir. Buna karşılık kişinin ihtiyarına ya da tercihine bırakılmayıp bir ödev/yükümlülük konusu olan, ihmal ve ihlali bir müeyyideye bağlanan normların varlığı söz konusudur ki bunlara hukuk kuralları denilmektedir. Bahse konu normlar, hak ve yükümlülükleri teminat altına almaya yönelik hukuki düzenlemeler bütünüdür. Söz konusu normlara uyulmadığında doğal olarak ya bireyin ya da toplumun/kamunun hakkını ihlal ya da ihmal gündeme gelmektedir. Şüphesiz her hak ihlali de beraberinde bireysel veya kamusal bir mağduriyeti getirmektedir. İşte mağduriyetin önüne geçmek ya da mağduriyet söz konusu olduğunda onun telafisinde devreye doğal olarak hukuk girmektedir. $\mathrm{Bu}$ bağlamda hukukun, özü itibariyle bireysel ya da toplumsal mağduriyetin önüne geçecek kurallar manzumesi olduğu ifade edilebilir. Söz konusu kural ya da hükümlerin merkezinde hakkaniyet ve adaletin temini yatmaktadır. Bu meyanda hukuk, adaletin temini ve hakkaniyet iklimini hâkim kılmak için vardır. Adaletin varlığı, doğal olarak toplumsal huzur ve mutluluğu, bu da bireylerin hukuka güvenini beraberinde getirecektir. Aksi durum ise, bireysel ve toplumsal güvensizliği, kamusal kaosu tetikleyecektir.

Adaletin temini ve hukuk güvenliği, yapısal/sistemsel bir mekanizmayı gerekli kılmakla beraber büyük ölçüde fertlerin sorumluluk anlayışı ile de yakından ilintilidir. Buna karşın hemen her bireyin aynı düzeyde sorumluluk bilincine sahip olduğunu ifade etmek mümkün değildir. Tarihsel süreç ya da insanın ontolojik miladı bu hususun en bariz kanıtı olarak dillendirilebilir. Hukuki yaptırımlar, cezalar bütünüyle bu tecrübenin hasılası olarak değerlendirilebilir.

Hukukta belirli nitelikleri haiz kimsenin serbest iradesiyle ve suç kastıyla hukuka aykırı bir eylemde bulunması suç olarak nitelendirilmektedir. Her suçun karşılığında da miktarı ve niteliği farklı olsa da maddi ve manevi bir yaptırım söz konusudur. Dolaysıyla insanın olduğu yerde bir suçun varlığ öteden beri değişmez bir olgu olarak karşımıza çıkmaktadır. Buna karşın sorumluluğunu bilen, hukuki hükümlere riayette gayet duyarlı bir kişinin serbest iradesiyle bir kusur, bir ihlal ve ihmale yönelik eyleme kastı olmamasına rağmen bir başka şahsın tehdit ve zor kullanması ile niteliği itibariyle hukuka aykırı fiilde bulunması söz konusu olabilir. 
$\mathrm{Bu}$ tehdit ve zorlama karşıllğında İslam hukuku literatüründe "ikrah" terimi kullanılmaktadır. Çoğu zaman bir güç kullanımı ile cana, mala, vücut bütünlüğüne karşı bir tehdidi ihtiva eden ikrahın cezaî sorumluluğa etkisi ve dolayısıyla hukuki sonuçları merak konusudur. Şüphesiz hukuki ilişkilerde kişinin irade özgürlüğü ve rızasının korunması, hak ve sorumlulukların dağılımında hür iradeye dayalı davranışların ölçü alınması hukukun temel amaçları arasındandır. Zorlama/cebir ve tehdide maruz kalan şahsın rıza ve serbest iradesinden bahsedilemeyeceği açıktır. Bu nedenledir ki zorlanan ya da tehdit altında kalan kimsenin söz ve davranışlarının sonuçlarında zorlayan ve zorlanan açısından hukuki bağlamda farklı bazı düzenlemeler yapılması ihtiyacı gündeme gelmiştir. Zira hukuki ilişkilerde irade serbestisinin ve rızanın varlığı, hak ve sorumlulukların taksim ve tespitinde esas alınması gereken temel unsurlardır. Araştırmamızda, ikrahın cezaî sorumluluğa etkisi ele alınarak hukuki sonuçları bağlamında değerlendirmeler yapılacaktır.

\section{Kavram ve Kapsam Olarak İkrah}

\section{1. İkrahın Tanımı ve Kapsamı}

Sözlükte, zorlamak ve kişiyi istemediği bir işi yapmaya sevk etmek ${ }^{1}$ anlamlarına gelen ikrah bir İslam hukuku terimi olarak; tehdit ettiği şeyi yapmaya muktedir/güç yetirebilecek kabiliyetteki bir şahsın, bir başka kişiyi, korkutmak ya da tehdit suretiyle kendi hâline bırakıldığında yapmaya rıza göstermeyeceği ve tercih etmeyeceği bir fiili işlemeye ya da bir sözü söylemeye sevk etmesi ${ }^{2}$ şeklinde tanımlanmaktadır. Osmanlı dönemi fakihlerinden Molla Fenârî (ö:834/1431) ise ikrahı; "Güçlü bir kimsenin, tehditle rızası olmayan bir insanı bir sözü söylemeye veya bir fiili işlemeye mecbur etmesi”’3 şeklinde tanımlamıştır. İslam dünyasının ilk kodifikasyon örneklerinden olan Mecelle'de ise ikrah; "Bir kimseyi korkutmak suretiyle rızası olmaksızın bir iş işlemek üzere haksız yere zorlamaktır." tanımlanmaktadır. Zorlayana "mükrih", zorlanan ya da tehdit altında kalan kimseye "mükreh", ikraha konu olan olaya "mükrehün aleyh", zorlayanın ikrahını gerçekleştirmek üzere zorlanana karşı kullandığı vasıtaya “mükrehun bih” kavramları kullanılmaktadır. $^{5}$

${ }^{1}$ Ebu'l Fazl Cemalüddin Muhammed İbn Mükerrem İbn Manzûr, Lisânü'l-Arab (Beyrut: Dâr-u Sâdır, ts.) 13/ 535.

${ }^{2}$ Şemsü'l-Eimme Muhammed b. Ahmed es-Serahsî, Kitâbü 'l-mebsût (Beyrût: Dâru'lMarife, 1978), 24/38; Muhammed Ebû Zehra, el-Cerîme ve'l-ukûbe fi'l-fikhı'lİslâmî (el-Cerîme) (Kahire: ts), 482.

${ }^{3}$ Şemsüddin Mehmed b. Hamza Fenarî, Fusûlu'l-bedâyi (İstanbul: 1289), 1/32.

${ }_{5}^{4}$ Mecelle, 948 madde.

${ }^{5}$ Serahsî, el-Mebsût, 24/39; Ali Bardakoğlu, ,"İkrah”, Türkiye Diyanet Vakfi İslâm Ansiklopedisi (İstanbul: TDV Yayınları, 2000), 22/30; Mesut Bayar, İslâm

Turkish Academic Research Review - Türk Akademik Araştırmalar Dergisi 
İslam hukukçuları haklı olarak merkeze aldıkları unsura göre bir ikrah tanımı yapmışlardır. Bu bağlamda ikrahta etkin olan baskı ve baskının ağırlığı unsuruna odaklanan fakihlerin tanımlarını bu çerçevede gerçekleştirdikleri ifade edilebilir. Buna karşılık ikrahın yönelik olduğu alan ve hukuka aykırılık unsurunu merkeze alan fakihlerin de ikrahın tanımını bu eksende yaptıkları görülür. ${ }^{6}$ Hangi açıdan bakılırsa bakılsın, insanın özgür irade ve rızasıyla normal koşullarda sergilemeyeceği bir tavır ve eyleme zorlanmasının ikrahın ortak noktasını teşkil ettiği söylenebilir. Bu itibarla ikrah, fiziksel ve psikolojik bir baskıyı, bir tehdidi havi eylemdir, tutumdur. Nitekim çağdaş İslam hukukçularından M. Ahmed Zerkâ, ikrahı, "Fiziki ya da bedensel bir zararla insan üzerinde baskı kurma veya zarar verme tehdidi ile korkutarak normal koşullarda rızası olmayan bir eylemi yapmaya veya terk etmeye zorlamaktır" 7 şeklinde tanımlamıştır. Bahse konu tehdit, çoğu zaman kişinin can, mal ve vücut tamlığına yöneliktir. Böyle bir vasatta kişiden sadır olan fiillerin hukuka aykırılığı, diğer şahıslara zarar içermesi, eylemin bütün unsurlarıyla teşekkül etmiş bir suç olarak nitelendirilmesi ve öngörülen ceza normunun uygulanması için kâfi değildir.

İkrah, bir şahsın, yapmak istemediği hukuki bir işlemi ya da hukuka aykırı bir fiili veya sözü, o şahsa zorla yaptırmak ya da söyletmektir. İslam hukukçuları, ikrahın her çeşidiyle zorlanan şahsın rızasını (bir şeyi arzu etmek ve onu memnuniyetle kabullenmek) kaldırdığı konusunda hemfikirdirler. Buna karşın Hanefiler ikrahın kişinin ihtiyarını bozmakla beraber temyiz gücünü yok etmediği, kişilerden hitap ehliyetini tamamıyla kaldırmadığı kanaatini taşımaktadırlar. Netice itibariyle Hanefi hukukçular, ister mülcî/tam ikrah olsun ister gayr-i mülcî/eksik ikrah olsun her iki çeşidiyle ikrahın rızayı ortadan kaldırdığını, ihtiyarın (bir işi yapıp yapmamada tercih imkanı) ise gayr-i mülcî ikrahta bozulmadığını, mülcî ikrahta bozulmakla beraber ortadan kalkmadığını belirtmişlerdir. ${ }^{8} \mathrm{Bu}$ bakımdan ikrahın

Hukukunda İkrâh ve Hukûkî Sonuçları (Ankara: Ankara Üniversitesi Sosyal Bilimler Enstitüsü, Doktora Tezi, 2012), 72 vd.

${ }^{6}$ Tanımlar için bkz. Bayar, İslâm Hukukunda İkrâh ve Hukûkî Sonuçları, 62.

${ }^{7}$ Mustafa Ahmed ez-Zerkâ, el-Medhalu'l-fikhi'l-âmm (Dımeşk: Dâru'l-Kalem, 1988), 452.

${ }^{8}$ Ebu Zehra, el-Cerîme, 487. 
ehliyete $^{9}$ etkisi söz konusu değildir. ${ }^{10}$ Şu kadar var ki, ikrah, İslam hukuk metodolojisinde, ehliyeti daraltan veya ortadan kaldıran (avârızu'l-ehliyye) sebepler kapsamında ele alınmıştır. ${ }^{11}$ Diğer taraftan İslâm hukuk doktrinine ilişkin kaleme alınan çağdaş araştırma ve yayınlarda ikrahın, ehliyet arızaları kapsamında değil rızayı bozan sebepler veya irade sakatlıkları bağlamında ele alınarak incelendiği görülür. ${ }^{12}$ Hanefi fakihlerin, farklı değerlendirmeler olmakla beraber ikraha ilişkin yapmış oldukları ince ve teknik ayrımın kavramsal hukuk metodolojisinin teşekkülü açısından dikkat çekici olduğunu ifade edebiliriz.

İkrah olgusunun kavramsal içeriğine kimi ayet ve hadisler dayanak teşkil etmektedir. Nitekim Kur'ân-1 Kerim’de değişik vesilelerle ikrah terimin geçtiği ayetlerde; dinde zorlamanın olmayacağ ${ }^{13}$, zor kullanım ve tehdit altında müminlerin inkâra yönelik sözlerinin imanlarına zarar vermeyeceği ${ }^{14}$, kadınların bir eşya gibi mirasa konu edilmeye zorlanmasının çirkinliği ${ }^{15}$, ikrah altında işlenen günahlarda Allah'ın bağışlayıcı ve merhametli olduğu ${ }^{16}$ ve kadınların fuhşa zorlanmaması

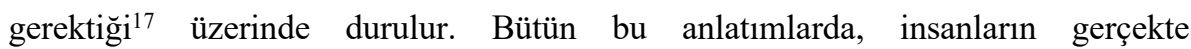
kabullenmedikleri, rızalarının olmadığı bir sözü söylemeye veya bir işi yapmaya zorlanması şeklinde ikraha ilişkin ortak bir anlam yatmaktadır. Diğer taraftan "Gönlü imanla dolu olduğu hâlde inkara zorlanan hariç kim iman ettikten sonra Allah'ı inkâr eder, kalbini inkara açık tutarsa, Allah'ın gazabı onların üzerindedir. Bunlara büyük bir azap da vardır."18 ayeti, ikraha hukuki bir sonuç bağlanıp bağlanmaması

9 Hukuk terminolojisinde ehliyet; kişinin hak ve yükümlülüklere konu olmaya elverişli oluşunu ifade eden bir terimdir. Bkz. A.Kerîm Zeydân, el-Vecîz fì usûli'lfikh (Beyrût: Mektebetu'l-Kuds, 1987), 92; Fahrettin Atar, Fılıh Usûlü (İstanbul: Marmara Üniv. İlahiyat Fakültesi Vakfı Yayınları, 1988), 143; Hüseyin Halef Cubûrî, Avarizu'l-ehliyye inde'l-usûliyyîn (Mekke:1988),70; Hasen M. Makbûlî elEhdel, Usûlu'l-fikhı'l-İslâmî (San'a: 1990), 217; Hayreddin Karaman, Mukayeseli Íslam Hukuku (İstanbul: Nesil Yayınları,1987), 1/178; Bardakoğlu, "Ehliyet", Türkiye Diyanet Vakfi Íslâm Ansiklopedisi (İstanbul: TDV Yayınları, 1994), 10/533539.

${ }^{10}$ Serahsî, el-Mebsût, 24/38.

${ }^{11}$ Bkz. İzzuddin Abdüllatîf b. Abdülaziz b. Melek, Şerhu'l-Menâr fi'l-usûl (İstanbul: ts.),369; Zeydân, el-Vecîz, 100; Cubûrî, Avârızu'l-ehliyye, 131; Abdürrezzâk Ahmed es-Senhûrî, Masâdirü'l-hakk fi'l- fikhı'l-İslâmî (Beyrût:1953), 2/186; Bardakoğlu, "Ikrah", 22/31.

12 Bardakoğlu, "İkrah", 22/31; H.İbrahim Acar, "İslâm Borçlar Hukukunda İradeyi Sakatlayan Sebepler II- İkrah", Atatürk Üniversitesi İlahiyat Fakültesi Dergisi 18 (Erzurum 2002), 19 vd.

13 el-Bakara 2/256; Yûnus 10/99.

14 en-Nahl 16/106.

15 en-Nisâ 4/19.

16 Tâhâ 20/73.

17 en-Nûr 24/33.

18 en-Nahl, 16/106.

Turkish Academic Research Review - Türk Akademik Araştırmalar Dergisi 
konusunda bir fikir vermektedir. Yukarıda geçen ayetlerin hemen hepsinde, ikrahın haksız bir fiil olarak nitelendirildiği, din gibi önemli bir meselede dahi zorlamanın kabul görmeyeceği, gerekli şartları haiz zorlama neticesinde mükrehin eylemlerinden dolayı günahkâr olarak nitelendirilmeyeceği dikkat çekmektedir.

Hz. Peygamber de (s.a.s.) "Şüphesiz Allah, ümmetimden hata, unutma ve (rızalarının olmadığı hâlde) zor altında yaptıkları şeylerden ötürü (doğacak sorumlulukları) kaldırmıştır."19 buyurmaktadır. Hz. Peygamberin bu sözü, ikraha ilişkin tespit ve değerlendirmelerde temel teşkil eden önemli bir dayanak olarak literatürdeki yerini almıştır. İslam hukukçuları da görüş farklılıklarına rağmen ikrahın, mükrehin söz ve fiillerinin hukuki sonuçlarına etki ettiği hususunda görüş birliği içindedir.

\section{2.İkrahın Çeşitleri}

İslam hukukçuları genelde tehdit unsurunun ağırlığını merkeze almak suretiyle ikrahı ayrıma tabi tutmuşlardır. İslam hukuk tarihinde çoğu zaman farklı kategorik ve teorik yaklaşımlar sergileyen Hanefi hukukçuların, İslam hukuk terminolojisinin/kavramsal fikhın teşekkülünde ciddi bir paya sahip olduklarını ifade edilebilir. Farz, vacip, sünnet, tahrimen ve tenzihen mekruh gibi ana ve ara ayrımlara baktığımızda, Hanefi fukahasının bahse konu ayrımlarda derin izleri görülür. $\mathrm{Bu}$ noktadan hareketle Hanefiler ikrahı, mülcî/tam, gayr-1 mülcî/eksik ve manevî/psikolojik ikrah şeklinde üçlü bir ayrıma tabi tutmuşlardır. Öyle ki, süreç içinde de ikrah, fikıh literatüründe müstakil bir başlık olarak ele alınmış ve bu bağlamda mükreh ve mükrihe yönelik tasarrufların hukuki sonuçları detaylandırılmıştır. Şimdi bu ayrımda yer alan ikrah çeşitlerine temas edeceğiz.

1) İkrah-1 mülcî/Tam zorlama: Kişinin canına, vücut tamlığına, servetinin tümüne veya yakınlarından herhangi birisinin can ya da vücut tamlığına yönelik baskı ve tehdit içeren zorlamadır. Bir başka ifadeyle tam ikrah, insanın eziyetine dayanıp katlanamayacağı bir şeyle tehdit edilmesidir. Bu çeşit ikrah, ihtiyarı (bir işi yapıp yapmama konusundaki tercih imkânını) bozar ve rızayı (bir şeyi gönülden isteme anlamındaki iradesini) ortadan kaldırır. ${ }^{20} \mathrm{Bu}$ tür bir ikrah, zaruret halinin de

19 Muhammed b. İsmail el- Buhârî, el-Câmi 'u's-sahîh (İstanbul: Çağrı Yayınları, 1992), "Itk", 6; Ebû Dâvûd Süleyman b. Eş'as es-Sicistânî, es-Sünen (İstanbul: Çağrı Yayınları, 1992), “Talâk”, 15; Muhammed b. Îsa Tirmizî, es-Sünen (İstanbul: Çağrı Yayınları, 1992), "Talâk”, 8;Ahmed b. Şuayb en-Nesâi, es-Sünen (İstanbul: Çağrı Yayınları, 1992), "Talâk”, 22; Ebû Abdullah Muhammed b. Yezîd İbn Mâce, es-Sünen (İstanbul: Çağrı Yayınları, 1992), "Talâk", 14.

${ }^{20}$ Muhammed Emin b. Ö̉mer İbn Âbidîn, Hâşiyetü Nesemâti'l-eshâr (Misır: 1979), 269; Alâuddîn Ebû Bekr b. Mes'ûd el-Kâsânî, Bedâiu's-sanâi' fì tertîbi'ş-şerâi' (Beyrût: Dâru'l-Kütübi'l-İlmiyye, 1986), 7/175; İbn Melek, Şerhu'l-Menâr fi'l-usûl (İstanbul, ts.), 369; Zeydân, el-Vecîz, 136; Saffet Köse, "İslam Hukukunda İkrahın 
sebeplerinden biri olarak değerlendirilir. Nitekim mükrehin satımı, zaruret halinde yapılan satımın en çok vurgulanan örneklerinden birini oluşturur. Fıkhî tartışmalarda ikrah terimi yalın olarak kullanıldığında genelde tam ikrah kastedilir. ${ }^{21}$ Görüldüğü gibi bu nevi ikrahta çok ciddi bir tehdit söz konusudur. Tehdidin gerçekleştirilmesi durumunda telafisi imkânsız sonuçlarla karşılaşmak olasıdır.

2) İkrah-1 gayr-i mülcî/Eksik zorlama: Zorlananın rızasını yok ettiği halde ihtiyarını ifsat etmeyen, mükrehin bir uzvunun sakatlanmasına sebep olmayacak derecede sadece üzüntü, keder ve maddi-manevi sıkıntı veren, az dövme, kısa sureli hapis gibi tehdit unsurlarını ihtiva eden ikraha denir. Bu tür ikrah, rızayı ortadan kaldırır fakat ihtiyarı bozmaz. ${ }^{22}$

3) Manevi/Psikolojik ikrah: Gerek ikrah-1 mülcî gerekse ikrah-1 gayri mülcî, ağırlık ve etkisi farklı olsa da doğrudan insanın psikolojisine tesir eden baskı ve zorlamalardır. Buna karşın manevi ikrah, bir kimseyi öldürme veya bir organını yok etme tehdidi gibi bir tehditle değil de onun yakın akrabalarından birinin hapsedileceği veya onlara bir zarar verileceği ya da eziyet edileceği şeklindeki bir tehdit ile olabilecek ikrahtır. Böyle bir ikrah, insandaki rızayı yok edemeyeceği gibi onun irade serbestisini de ortadan kaldırmaz. Çünkü böyle bir tehdit karşısında insan ancak akrabasına olan bağlılı̆ıından dolayı acı duyar, gam ve kedere boğulur. Bu bakımdan da tam bir irade serbestisine sahip olamaz. Normal kıyasa göre böyle bir ikrah geçerli değildir. Fakat istihsanen bu da bir tür ikrah olarak telakki edilmiştir. ${ }^{23}$

Mukayeseli İslam hukuku eserlerinde, "Hanefilerde üçüncü bir çeşit ikrah daha vardır ki, bu da manevî ikrahtır. Manevî ikrah rızayı tamamen ortadan kaldırırken ihtiyarı/seçme hürriyetini ortadan kaldırmaz" denilmek suretiyle manevi ikrahta rızanın bulunmadığı dile getirilir. ${ }^{24}$ Fukaha arasında bu hususta çerçeveyi oldukça dar tutan Hanbelîler, oğluna eziyetle tehdit edilen babayı zorlanan saymakta; fakat oğul dışında herhangi bir akrabaya eziyetle tehdidi ikrah olarak kabul etmemektedirler. Bu konuda Şafî̂ hukukçuların yaklaşımı oldukça kapsamlıdır. Nitekim onlara göre, mükrehin zevi'l-erhamdan bir yakınına yönelik işkence

Sözlü Tasarruflara Tesiri”, Diyanet İlmi Dergi 32/2 (Ankara 1996), 37; Ehdel, Usûl, 237; Atar, Flkıh Usulü, 154.

${ }^{21}$ Bardakoğlu, "İkrah", 22/33.

${ }^{22}$ Kâsânî, Bedâi's-sanâi' 7/175; Alâuddîn Abdülazîz b. Ahmed b. Muhammed elBuhârî, Keșfu'l-esrâr fî şerhi Usûli'l-Pezdevî (İstanbul:1308), 4/1503-1507; İbn Melek, Şerhu'l-Menâr, 369; Zeydân, el-Vecîz, 137; Atar, Usul, 154; Ehdel, Usûl, 237; İsmail Bilgili, "Ehliyet Arızalarından İkrah Sartları ve Kısımları" İstanbul Üniversitesi İlahiyat Fakültesi Dergisi 1/1 (Bahar 2010), 261.

${ }^{23}$ Serahsî, el-Mebsût, 24/143-144; Hakkı Aydın, "İslam ve Türk Borçlar Hukukunda İkrah”, Atatürk Üniversitesi Illahiyat Fakültesi Dergisi 11 (1993), 307.

${ }^{24}$ İbn Kudâme, el-Mugnî, 7/120; Bilgili, Ehliyet Arızalarından İkrah Şartları ve Kisımları", 264.

Turkish Academic Research Review - Türk Akademik Araştırmalar Dergisi 
tehdidinde bulunulması ikrah olarak değerlendirilmektedir. Ayrıca mükrehin zevi'lerham kabul edilen yakınlarından birine yönelik öldürme, yaralama gibi tehditte bulunmak da ikrah olarak değerlendirilir. ${ }^{25}$ Manevi ikrah konusunda Şafii mezhebinin görüşünün daha kapsamlı ve isabetli olduğu kanısındayız. Burada tehdidin ağırlığı dikkate alınmak suretiyle mükrihin/zorlayanın eyleminin ikrah-1 mülcî veya gayr-i mülcî kapsamında ele alınması ve ona göre hukuki sonuçlar bağlanmasına imkân tanınmaktadır. Dolayısıyla bahse konu ikrah çeşidinin farklı bir başlık altında değil de tehdidin ağırlığının dikkate alınması suretiyle mülcî ya da gayr-i mülcî ikrah kapsamında değerlendirilmesinin isabetli olacağı kanısındayız.

Diğer taraftan günümüzde oldukça sıkça gündeme gelen bir çeşit psikoloji baskı, taciz, eziyet olan mobbing konusu da manevi ikrah kapsamında değerlendirilebilir mi? sorusu zihinleri meşgul edebilir. Mobbing, gündelik kullanımı içinde, birine karşı cephe oluşturma, küçük düşürücü hareketlerde bulunma, hedef aldığı kişiyi uyumsuzlukla suçlama, yalnızlaştırarak bunaltma ve kötü niyetli davranışlar, imalar ve dışlayıcı tutumlar biçiminde işleyen olumsuz bir iletişim süreci ${ }^{26}$ olarak tanımlanmaktadır. Mobbing de şüphesiz bir baskı vardır. Ancak teknik anlamda ikrah, öldürme, dövme, hapis, mal itlafı gibi fiziki baskıyı ihtiva eden tehdittir. Dolayısıyla hukuk literatüründeki ikrah kavramı ile mobbing tehdit ya da baskı ağırlığı, tehdidin zorlanan şahsın irade ve ihtiyarına etkisi itibariyle aynı kapsamda değerlendirilebilecek türden taciz ve zorlamalar değildir.

Hanefilerin ikraha ilişkin yukarıda bahsettiğimiz üçlü ayrımına karşın diğer fakihler mükrehe/zorlanana yönelik öldürme, şiddetli dövme, hapsetme gibi fiziksel tehdidi içeren baskıyı dikkate almak suretiyle ikrahı kısımlarına ayırmaksızın bir hükme varmışlardır. Bu bağlamda zorlananın saygın biri olup olmaması ile kendisine dokunacak zararın derecesinin ikrahın varlığının tespitinde etkin olduğunu ifade etmişlerdir. Bu fakihlere göre, ikrahta önemli olan mükrehin uğradığı zarardır bir başka ifadeyle ikrahın konusu tehdittir. Tehdit unsurunun cana ya da vücut tamlığına ilişkin oluşu, yaralayıcı dövme, hürriyeti kısıtlama gibi hususlar ikrahı sabit kılmaktadır. Bu grupta yer alan İslam hukukçuları, toplumda saygın bir yeri olan makam, mevki ve itibar sahibi bir kişinin ölümüne veya vücut tamlığına yönelik olmayacak derecedeki dayak, kısa süreli hürriyetini kısıtlama ve benzeri davranışları

${ }^{25}$ Abdulkâdir Ûdeh, et-Teşrîu'l-cinâiyyü'l-İslâmî mukârenen bi'l-kânûni'l-vad'î (Beyrût: ts.), 2/309; Bilgili, Ehliyet Arızalarından İkrah Şartları ve Kısımları”, 264.

${ }^{26}$ Burcu Özkul-İlker H.Çarıkçı, "Mobbing ve Türk Hukuku Açısından Değerlendirilmesi”, Süleyman Demirel Üniversitesi İktisadi ve İdari Bilimler Fakültesi Dergisi 15/1 (Isparta 2010), 483. 
tam ikrah kapsamında değerlendirirler. ${ }^{27} \mathrm{Bu}$ itibarla Hanefîler dışındaki mezheplerde ikrah, mülcî ve gayr-i mülcî şeklinde bir ayrıma tâbi tutulmamıştır. Diğer mezhepler genelde Hanefîlerin tam zorlama/ikrah-1 mülcî olarak nitelendirdikleri kısmın kapsamına giren tehditlerle ikrahın gerçekleşmiş sayılacağını ifade etmişlerdir. Hanefîlerin gayr-i mülcî ikrah kavramı kapsamında değerlendirdikleri tehditlere gelince, Şâfî̂ ve Hanbelî mezhepleri, bu tehditlerin ikrah sayılıp sayılmayacağı konusunda, farklı iki görüş ileri sürmüşlerdir. ${ }^{28}$ Mâlikîler ise, bu nitelikteki tehditleri bazı konularda (dinden çıkmayı gerektirecek sözleri söylemek gibi) ikrah konumunda değerlendirirler. Bazı hukuki işlemlerde ise, bu çeşit tehditlerin ikrah olarak değerlendirilemeyeceğini belirtmişlerdir. ${ }^{29}$

Zarar ya da tehdidin ikrah olarak değerlendirilip değerlendirmemesinde buna mâruz kalan kimsenin algılama biçimi kadar zorlama konusu fiilin ağırlık derecesi de etkili ve hukuki sonuçlar açısından belirleyicidir. Böyle olunca fakihlerin ikrahın tespit ve ayırımında benimsedikleri bu esnek tavır ilk bakışta hukukun objektifliğini ve hukuk güvenliğini zedeler gibi görünse de her olayın kendi şartları içinde değerlendirilmesine imkân verdiği için hakkaniyet hukukunun ve Hanefilerin istihsan anlayışının örneklendirmesi olarak da değerlendirilebilir. Diğer taraftan Hanefilerin ikrahı tam ikrah/ikrah-1 mülcî ve eksik ikrah/ikrah-1 gayri mülcî şeklindeki ayırımı, kanaatimizce mükrehin eylemlerine bağlanacak hukuki sonuçlar tasnifi açısından daha sağlıklı çıkarımlar yapılmasına imkân tanımaktadır. Çünkü her ikrahı aynı düzlemde ele almak isabetsiz sonuçları beraberinde getirebilir. Kişinin kendisi, yakınları veya bir insanın canına ve vücut tamlığına karşı bir tehdidin ağırlığı ile şiddeti her ne olursa olsun ölüme sebebiyet vermeyecek ölçüdeki dövme, hapsetme veya sözlü tehditler aynı konumda değerlendirilmez.

\section{3.İkrahın Şartları}

Hukuki bağlamda ikrahın gerçekleşmesi ve sonuç doğurması için zorlama ve tehditte bulunan kimse/mükrih, buna mâruz kalan şahıs/mükreh, yapılması veya terkedilmesi istenen fiil/mükrehün aleyh, cebir ve tehdit türü/mükrehün bih şeklindeki

27 Ebû Muhammed Abdullah b. Ahmed b. Muhammed İbn Kudâme, el-Muğnî (Beyrut: Dâru'l-Kütübi'l-İlmiyye, ts.), 7/120; Ebû Zekeriyyâ Yahya b. Şeref enNevevî, Muğni'l-muhtâc (Beyrut: ts.) 3/289; Bilgili, "Ehliyet Arızalarından İkrah Şartları ve Kısımları", 262.

${ }^{28}$ İbn Kudâme, el-Mugnî, 8/260; Ebû Yahya Zekeriyya b. Muhammed el-Ensâri, Esne'l-metâlib şerhu Ravzati't-tâlib (by.:ts.), 3/282; Vehbe Zuhaylî, el-Fıkhu'lİslâmî ve edilletuhû (Dımeşk: 1989), 5/387.

29 Ebû Abdullah Muhammed el-Mağribî el-Hattâb, Mevâhibu'l-celîl li şerhı muhtasari Halîl ( Beyrût:1992) 3/45; Zeynüddin b. İbrahim b. Muhammed İbn Nüceym, el-Bahru'r-râik şerhu Kenzi'd-dekâik (Beyrût:ts.), 8/ 80.

Turkish Academic Research Review - Türk Akademik Araştırmalar Dergisi 
dört unsurdan hemen her birine özgü şartlar aranmaktadır. ${ }^{30} \mathrm{Bu}$ itibarla ikrahın varlığından söz edilebilmesi için bahse konu unsurların her birine ilişkin şartların gerçekleşmesi gerekir. Şu kadar var ki, ikrah rızayı yok edip irade ve ihtiyarı sakatladığından bu sonucu doğuran her türlü cebir ve tehdidin ikrah olarak nitelendirilmesi gerekir. Ancak bu durum her olaya, özellikle de ikraha maruz kalan kimsenin içinde bulunduğu şartlara, ruh hali ve algılama biçimine göre farklılık gösterebilecek değişkenlik ve esneklikte bulunduğu, öte yandan hukukun uygulanmasında güvenlik ve istikrarı sağlayacak bazı objektif belirlemelere gidilmesi zorunlu olduğu için herhangi bir tehdidin ikrah olarak değerlendirilmesinde böyle bir kuralla yetinilmesi mümkün değildir. İkrahın şartları konusunda gündeme gelen ayrıntılar, bu belirlemeyi tespite yönelik gayretler olarak değerlendirilebilir. ${ }^{31}$ Bahse konu unsurlarla ilgili şartlardan konumuza 1şık tutacak ve cezaî sorumluluğa ilişkin tespitlerimize yeterli derecede katkı sağlayacak nitelikteki genel şartları aktarmakla yetineceğiz. Bu itibarla ikrahın hukuken geçerliliği için gerekli şartları şu şekilde özetlemek mümkündür:

1) Zorlayan, tehdit ettiği şeyi yapabilecek güç ve imkâna sahip olmalıdır. Buna göre zorlayan şahsın, tehdit konusu eylemi gerçekleştirmeye gücü yetmiyor ve zorlanan da bunu biliyorsa, olay hukuki açıdan ikrah kapsamında değerlendirilmez. ${ }^{32}$ Hanefilerden Ebû Yûsuf ve İmam Muhammed, ikrahın tehdidini yerine getirebilecek güce sahip herhangi bir şahıstan gelebileceğini ileri sürerken Ebû Hanîfe ancak devlet başkanından gelen tehdidi ikrah kapsamında sayar. Ebu Hanife'nin farklı bir görüşe sahip olması, deliller kaynaklı bir ihtilaf değil yaşamış olduğu zaman diliminin sosyo-politik yapılanmasının doğal bir sonucudur. Zira bu görüş, o dönemde mükrehin başka kimselerden gelecek ikrah durumunda devlet başkanının korumasına sığınma imkânı ile irtibatlıdır. Ebû Yûsuf ve İmam Muhammed'in yaşadığı dönemde ise, bozulmalar baş göstermiş, eşkıyalık ve anarşi yaygınlaşmış ve her zorba tehdit ettiğini yapabilecek duruma gelmiştir. ${ }^{33}$ Dolayısıyla tehdit ve zorlamanın devlet başkanı ile sınırlı tutulması makuliyet ve meşruiyet zeminini

${ }^{30}$ Bkz. Bayar, İslam Hukukunda İkrah, $107 \mathrm{vd.}$

${ }^{31}$ Bardakoğlu, "İkrah", 22/32

${ }^{32}$ Serahsî, el-Mebsût, 24/39; Kâsânî, Bedâiu' 'sanâi', 7/176; Muhammed b. Ferâmuz b. Ali Molla Hüsrev, Dureru'l-hukkâm fì şerhi Gureri'l-ahkâm (İstanbul: 1319), 2/270; İbn Kudâme, el-Mugnî, 8/261; Abdurrahman b. Muhammed b. Süleyman Dâmâd, Mecmau'l-enhur (İstanbul: 1276), 2/429; Köse, "İslam Hukukunda İkrahın Sözlü Tasarruflara Tesiri”, 36; Zeydân, el-Vecîz, 135.

${ }^{33}$ Kasânî, Bedâiu's-sanâi ${ }^{6}, 7 / 176$. 
kaybetmiştir. Son dönem İslam hukukçularından Ö. Nasuhi Bilmen, İmameynin görüşünü tercihle "İkrahın tahakkuku için vuku bulduğu yerde hükümetin, hâkimin bulunması şart değildir. Binaenaleyh İstanbul gibi bir şehirde vukuu mümkün ve davası muteberdir..."34 ifadesiyle ikrahın yönetimsel, mekânsal ve dönemsel bir olgudan ziyade mükrehe yönelik tehdit ve baskının gerçekleşme ve gerçekleştirilme olasılık ve imkânı ile ilintili bir durum olduğuna dikkat çekmiştir. Nitekim yaşadığımız modern zamanlarda dahi nice güvenlik önlemlerine rağmen şahısların türlü tehdit ve zorlamalara maruz kaldıkları ve istemedikleri nice suçu işlemek durumunda bırakıldıklarına tanık oluyoruz.

2) İkrahın gerçekleşme olasılığında zorlayanın/mükrihin aklî ve bedenî yetişkinliğe ulaşması şart değildir. Kendisine itaat edilen mümeyyiz çocuk ve matuh baliğin zorlamasıyla da ikrah sabit olur. ${ }^{35}$

3) Zorlanan şahsın, zorlayan kişinin tehdit ettiği şeyi derhal yapacağına kanaat getirmesi veya bunu yakinen bilmesi ve bunun etkisi altında ikraha konu eylemi yapması. Buna göre, zorlanan kişi, zorlayanın tehdidinden kaçmak, hileye başvurmak, başkasından yardım istemek ve karşı koymak gibi yollarla kurtulma gücünden yoksun olmadıkça, söz konusu tehdit ya da zorlama hukuki açıdan ikrah konumunda değerlendirilmez. ${ }^{36}$

4) Zorlananın eda ehliyetine sahip olması gerekir. Eda ehliyeti olmayan veya tasarruflarından sorumlu kabul edilmeyen çocuk ya da akıl hastasına yönelik ikrah geçerli değildir. ${ }^{37}$

5) Zorlanılan fiilin yapılması veya söz ise söylenmesi, tehditle aynı zaman diliminde vaki olmalıdır. Araya zaman farkının girmesi, ikrahın hukuken geçersizliğine sebebiyet verir. ${ }^{38}$

34 Ö.Nasûhi Bilmen, Huk̂kkı İslâmiyye ve Istılahatı Fıkhıyye Kamusu (İstanbul: Bilmen Yayınevi, 1985), 7/320.

${ }^{35}$ Bilgili, "Ehliyet Arızalarından İkrah Şartları ve Kısımları", 249.

${ }^{36}$ Serahsî, el-Mebsût, 24/39; Kâsânî, Bedâiu's-sanâi' , 7/ 176; İbn Kudâme, el-Mugnî, 8/261; Cubûrî, Avarızu'l-ehliyye, 475; Ûdeh, et-Teşrîu'l-cinâiyyü'l-İslâmî, 1/568; Zeydân, el-Vecîz, s. 135; Köse, "İslam Hukukunda İkrahın Sözlü Tasarruflara Tesiri", 36.

37 Serahsî, el-Mebsût, 24/43;Bilgili, "Ehliyet Arızalarından İkrah Şartları ve Kisimlari”, 250.

${ }^{38}$ Muhammed Emin b. Ömer İbn Âbidîn, Reddü 'l-Muhtâr ala'd-Dürri'l-muhtâr, thk. Âdil Ahmed Abdülmevcûd-Ali Muhammed Muavvaz (Beyrût: 1994), 9/178; Alauddîn Muhammed b. Ali el-Hısnî el-Haskefî, ed-Durru'l-muhtâr (Reddu'lMuhtâr'la) (Beyrût:1994), 9/178; Ûdeh, et-Teşrîu'l-cinâiyyü'l-İslâmî, 1/567; Köse, "İslam Hukukunda İkrahın Sözlü Tasarruflara Tesiri”, 36.

Turkish Academic Research Review - Türk Akademik Araştırmalar Dergisi 
6) Tehdidin konusu, öldürme, bazı organların itlafı, hapis, vurma vb. şeyler olmalıdır. ${ }^{39}$ Mala karşı yapılan tehdit -eğer mal çok ise- Şâfîi, Mâlikî, Hanbelî ve bazı Hanefî hukukçularına göre, zorlama kapsamında değerlendirilmiştir. ${ }^{40}$ Hanefî mezhebindeki hâkim görüşe göre, zorlama konusunun mal olması durumunda, mala verilecek zarar ne kadar büyük olursa olsun, yapılan fiil, hukuken zorlama olarak değerlendirilmez. ${ }^{41}$ Fakihlerin çoğunluğu, kişinin eş ve yakınlarına karşı yapılan tehdidin de ikrah kapsamında değerlendirileceğini ifade etmişlerdir. ${ }^{42}$

\section{Kavram ve Kapsam Olarak Cezaî Sorumluluk}

\subsection{Tanımı ve Kapsamı}

İnsan, sorumlu bir varlık olarak yaratılmıştır. İnsanın sahip olduğu hak ve yükümlülüklerin netice itibariyle sorumluluk ile yakın ilişkisi vardır. Ontolojik bağlamda da Kur'an-1 Kerim'de insanın “emanet” kavramının kapsamına giren hususları yüklenmesi43 ${ }^{43}$ onun sorumluluğa ehil bir varlık olduğunu gösterir. Söz konusu ayetteki "emanet” kavramına hangi anlam yüklenirse yüklensin netice itibariyle emanet onu muhafaza sorumluluğunu haiz bir varlığa tevdi edilecektir. ${ }^{44}$ Zemahşerî ve Fahreddin Râzî gibi müfessirler ayetteki emanetin “yükümlülük/teklif” anlamına geldiğini ifade etmişlerdir. ${ }^{45}$ Nitekim "İnsan, kendisinin başı boş bırakılacağını mı sanır?"46 ayeti de insanın sorumlu bir varlık olduğunu dile getirmektedir. Diğer taraftan toplum halinde huzur ve uzlaşı içinde yaşamanın en

39 Şemsuddîn Muhammed b. Abdillâh Timurtâşi, Tenvîru'l-ebsâr ve câmiu'l-bihâr (Reddu'l-Muhtâr'la) (Beyrût 1994) 9/178; İbn Kudâme, el-Mugnî, 8/261; Cubûrî, Avarızu'l-ehliyye, 476; Ûdeh, et-Teşrîu'l-cinâiyyü'l-İslâmî, 1/565.

${ }^{40}$ Zeynüddin b. İbrahim b. Muhammed İbn Nüceym, el-Bahru'r-râik şerhu Kenzi'ddekâik (Beyrût:ts.), 8/82; Ebû İshak İbrahim b. Ali eş-Şîrâzî, el-Mühezzeb (Beyrut: Dâru'l-Fikr, ts.), 2/83; İbn Kudâme, el-Mugnî, 8/261; Ebû Abdullah Muhammed elMağribî el-Hattâb, Mevâhibu'l-celîl li şerhı Muhtasari Halîl (Beyrût: 1992), 4/45; Ensârî, Esne'l-metâlib, 3/282; Zeydân, el-Vecîz, 135.

41 Serahsî, el-Mebsût, 24/93; İbn Nüceym, el-Bahru'r-râik, 8/ 82; İbn Âbidîn, Reddü'l-muhtâr, 9/178; Ûdeh, et-Teşrîu'l-cinâiyyü'l-İslâmî, 1/ 567.

42 Serahsî, el-Mebsût, 24/93; İbn Âbidîn, Reddu'l-muhtâr, 9/179; İbn Kudâme, elMugnî, 7/120; Ûdeh, et-Teşrîu'l-cinâiyyü'l-İslâmî, 2/310; Zuhaylî, el-Fıkhu'lİslâmî, 5/387.Zeydân, el-Vecîz, 135.

${ }^{43}$ el-Ahzâb 33/72.

${ }^{44}$ Ayetin yorumu için bkz. Ebû Abdillah Muhammed b. Ahmed el-Kurtubî, el-Câmi ${ }^{6}$ li ahkâmi'l-Kur'ân (Beyrut: Risale, 2017), 16/244; Abdullāh b. Ömer b. Muhammed el-Beydâvî, Envâru't-Tenzîl ve esrâru't-Te'vîl, (Beyrut: Daru'l-Fikr, 2001), 2/843.

${ }^{45}$ Fahruddin Muhammed b. Ömer er-Râzî, et-Tefsîru'l-Kebîr (Beyrut: 2005), 25/206; Mahmud b. Ömer ez-Zemahşerî, el-Keşşâf an hakâikl 't-tenzîl ve uyûni'l-akâvîl fî vucûhı't-te'vil (Kahire) 3/276-277.

46 el-Kiyâme 75/36. 
önemli unsuru bireylerin sorumluluklarının farkında oluşuna bağlıdır. Bu itibarla sorumluluk; "Bir kimsenin, kendisinin ya da başkalarının davranışları için bir kimseye ya da bir yetkiliye hesap verme, bu davranışların doğurabileceği sonuçlara katlanmayı kabul etme zorunluluğu ya da bunun ahlak açısından gerekliliği”"47 olarak tanımlanmıştır.

İslâm hukuk terimi olarak sorumluluk; "Uyulması gereken bir kurala aykırı davranışın hesabını verme, tazminatla yükümlü tutulma, işlenmiş bir suçun gerektirdiği cezayı çekmedir." ${ }^{48}$ Kısaca sorumluluk; belli bir hukuk kuralının ihlali veya ihmaline bağlanan maddi ve manevi yaptırıma katlanma yükümlülüğü şeklinde tanımlanabilir.

Cezaî sorumluluk ise; bir şahsın, serbest irade ve doğuracağı sonuçları bilerek (temyiz gücü), işlemiş olduğu yasak/hukuka aykırı fiillerin neticesine katlanmas $1^{49}$ şeklinde tanımlanmaktadır. İslam hukukuna ilişkin kaleme alınan çağdaş dönem Arap dilindeki eserlerde cezaî sorumluluk karşllığında “ "السؤولية الجنائية " terimi kullanılmaktadır. ${ }^{50}$

\subsection{Sorumluluğun Çeşitleri}

Çağdaş İslam hukuk literatüründe hem konusu hem de yaptırımı itibariyle iki tür temel sorumluluktan bahsedilmektedir. Bunlardan biri araştırma konumuz olan cezaî sorumluluk, diğeri de medenî sorumluluktur. Hukukta medenî sorumluluk yerine hukukî sorumluluk teriminin kullanımı yaygınlık kazanmıştır. ${ }^{51}$ Hukukî/Medenî sorumluluk; bir şahsın, hukuka aykırı ya da haksız fiili sonucunda bir şahsa verdiği maddi ve manevi zararı tazmin etme yükümlülüğüdür. ${ }^{52}$ Hukukî sorumlulukta bir ihmal ya da ihlal daha öz bir ifadeyle hukuka aykırılığın varlığı söz konusudur. ${ }^{53}$ Neticede bir mağdur ve bir de hak ihlalinde bulunan fail söz konusudur.

${ }^{47}$ Bayar, İslâm Hukukunda İkrâh, 17.

${ }^{48}$ Kemal Yıldız, "Sorumluluk", Türkiye Diyanet Vakfi İslâm Ansiklopedisi (İstanbul: 2009), 37/380.

49 Ûdeh, et-Teşrîu'l-cinâiyyü'l-İslâmî, 1/380; Misfir Gurmullah ed-Dümeynî, elCinâye beyne'l fikhı 'l-İslâmî ve'l-kânûni'l-vad' î (Cidde: ts.), 80; Abdülaziz Âmir, Şerhu'l ahkâmi'l âmme li'l cerîme (Bingazi: Câmiatü Karyûnus,1987), 285; A.Fethî Behnesî, el-Mevsûatü'l-cinâiyye fi'l-fikhi'l-İslâmî (Beyrût:1991), 4/293; Vehbe Zuhaylî, Nazariyyetü'd-damân ev ahkâmü'l-mesûliyyeti'l-Medeniyye ve'l-cinâiyye fi'l-fikhi'l-İslâmî (Dımeşk: 1982), 273.

${ }^{50}$ Ûdeh, et-Teşrîu' l-cinâiyyü'l-İslâmî, 1/380; Ebû Zehra, el-Cerîme, 392;Behnesî, elMevsûatü'l-cinâiyye, 4/293.

${ }_{51}$ Bayar, İslâm Hukukunda İkrâh, 19.

52 A. Naim İnan, Borçlar Hukuku (Ankara: 1973), 2/361; Karaman, İslam Hukuku, 2/469; Zuhaylî, Nazariyyetu'd-damân, 234.

${ }^{53}$ Bkz. Ünal Yerlikaya, "Hanefî Borçlar Hukuku Literatüründe Teaddî Kavramının Anlam Çerçevesi: Teaddî-Hukuka Aykırılık-Kusur İlișkisi Bağlamında Bir İnceleme”, Diyanet Illmi Dergi, 3/53 (Temmuz 2017), 25-51.

Turkish Academic Research Review - Türk Akademik Araştırmalar Dergisi https://dergipark.org.tr/tr/pub/tarr 
$\mathrm{Bu}$ tür sorumlulukta kişiye verilen maddi veya manevi zarar karşılığında tazmin sorumluluğu hukukî sorumluluğun temel konusunu teşkil etmektedir. Diğer taraftan bu tür sorumlulukta kişinin ceza ehliyetini haiz oluşu ya da olmayışı tazmin sorumluluğu ile ilzam bağlamında gerekli değildir. Aynı şekilde ceza ehliyetini haiz olmakla beraber suç kastı bulunmaksızın taksirle işlenen haksız fiiller karşılığında da hukukî sorumluluk gündeme gelir. Taksirle adam öldürülmesinde kısas değil diyete hükmedilmesi, bu tür bir sorumluluğun gereğidir.

Cezaî sorumluluk ise; bir şahsın, serbest irade ve doğuracağı sonuçları bilerek (temyiz gücü) suç kastıyla işlemiş olduğu yasak/hukuka aykırı fiillerin neticesine katlanması ${ }^{54}$ şeklinde tanımlanmaktadır. Tanımından da anlaşılacağı üzere cezaî sorumluluk, temyiz gücüne sahip bir bireyin serbest iradesiyle başkalarına karşı sözlü ve fiili olarak suç kapsamında değerlendirilen haksız saldırıda bulunması neticesinde kanunda/hukukta öngörülen cezaya katlanma sorumluluğudur. Şüphesiz cezaî sorumluluğun varlığı, serbest irade, temyiz gücü ve kişiye isnat edilen kusur ile yakından ilintilidir. Ceza hukukunda kusur, kasıt ve taksir olmak üzere ikiye ayrılmaktadır. Kusurun en yoğun derecesi, kasıttır. Kasıt; kişinin iradesinin bir sonucu elde etmek üzere herhangi bir fiile yönelmesidir. Kusurun hafif derecesi, bugünkü ceza hukukunda taksir diye ifade edilen "hata"dır. ${ }^{55}$ Suç kastının, serbest iradenin, temyiz gücünün ve hukuka aykırılığın bulunmadığı durumlarda cezaî sorumluluğun varlığından söz edilemez. Burada cezaî sorumluluğu bulunmayan şahsın hukukî sorumluluğunun da olmayacağı sonucu çıkmaz. Zira hukukî sorumlulukta, hukuka aykırılık ya da zararın varlığı ile failin fiili arasında illiyet bağının kurulması sorumluluk için yeter şarttır.

\subsection{Cezaî Sorumluluğun Hukuki Zemini}

İslam hukukunda, öteden beri bir suçtan dolayı ancak serbest irade ve temyiz gücüne sahip bulunan ve kendilerine kusur isnadı mümkün olan kimseler sorumlu tutulmuştur. İnsan yaratılışı itibariyle, irade ve seçme kudretine sahip kişiliği olan bir varlıktır. Kur'ân-1 Kerim'de birçok ayette, değişik vesilelerle insanın seçme ve fiillerine yön verme yetisine sahip olduğu dile getirilir. ${ }^{56}$ "De ki: Hak, Rabbinizdendir. Öyle ise dileyen iman etsin, dileyen inkâr etsin." ${ }^{57}$ ayetini bu

${ }^{54}$ Ûdeh, et-Teşrîu'l-cinâiyyü'l-İslâmî, 1/380; Dümeynî, el-Cinâye, 80; Âmir, Şerhu'l ahkâmi'l âmme, 285; Behnesî, el-Mevsûatü'l-cinâiyye, 4/293; Zuhaylî, Nazariyyetü'd-damân, 273.

55 Tahir Taner, Ceza Hukuku (İstanbul: 1949), 323; Reşat Dursun Tesal, Ceza Hukuku (İstanbul: 1979), 40; Ayhan Önder, Ceza Hukuku Dersleri (İstanbul: 1992), 267; Ûdeh, et-Teşrîu'l-cinâiyyü'l-İslâmî, 1/432; Dümeynî, el-Cinâye, 92; A. Fettâh Hadr, el-Cerîme (by.: 1985), 324.

${ }^{56}$ Bkz. en-Necm 53/39; Fussilet 41/46.

57 el-Kehf 18/29. 
bağlamda zikredebiliriz. Herhangi bir şahsa isnat edilen suça karşılık öngörülen cezanın uygulanmasında, ortaya çıkan zararın onun fiilinden doğmuş olması yeterli bir gerekçe değildir. Ayrıca söz konusu fiilde, failin kusuru yanında serbest irade ve temyiz gücüne de sahip olması şartları aranır. Çünkü serbest irade ile işlenmiş suçla, böyle bir iradeden yoksun şahsın işlediği suça aynı cezanın uygulanması, adalet ve hakkaniyet prensipleriyle bağdaşmaz. Neticeleri bakımından fiiller her ne kadar aynı sonucu doğursalar da eylem sahipleri aynı psikoloji, aynı irade ve temyiz gücüne sahip olmadıklarından, aynı cezaya çarptırılamazlar. Aksi takdirde bu, yaygın ifadesiyle teklif bi mâ lâ yutâk/şahsı güç yetiremediği bir şeyle yükümlü tutmak olur ki, bu da ayet $^{58}$ ve hadislerle ${ }^{59}$ yasaklanmıştır. ${ }^{60}$ Nitekim Kur'ân-1 Kerim'de "Allah, her şahsı, ancak gücünün yettiği ölçüde mükellef kılar..."61 ayeti bu yasağın hukuki temelini teşkil etmektedir. Aynı şekilde Peygamber de (s.a.s.) : "Allah, ümmetimden, hata (yanılarak), unutma ve zor altında yaptıkları (şeyler sonucunda meydana gelen fiillerin sorumluluğunu) kaldırmıştır."62, "Üç kimseden kalem (sorumluluk) kaldırılmıştı;; ergenlik çağına ulaşıncaya kadar çocuktan, uykudan uyanıncaya kadar uyuyandan, kendine gelinceye kadar akıl hastasından”63 sözleriyle kişilerin güçleri üstünde herhangi bir yükümlülükle sorumlu tutulmayacaklarını vurgulamıştır.

Suç işleyen kimsenin, suçu işlediği anda içinde bulunduğu psikolojik durum ile, suç arasındaki ilişki ve orantıyı ifade eden ve bu surette sorumluluk derecesinin belirlenmesini sağlayan unsura, suçun manevi unsuru denilmektedir. ${ }^{64}$ "Kusurluluk" terimi ile de ifade edilen manevi unsur, herhangi bir suç karşıllı̆̆ında belirtilen cezanın uygulanabilmesi için suçta bulunması gerekli en önemli unsurlardan birisini teşkil etmektedir. Bu unsur bulunmadıkça, meydana gelen fiil, hukuki anlamda suç olarak nitelendirilemediği gibi faile ceza da uygulanamaz. ${ }^{65}$

Hukukun suç olarak nitelendirdiği bir fiili işleyen şahsa suç karşıllığında öngörülen cezanın uygulanabilmesi için suçu işlemedeki kastı/suç kastı, serbest irade

${ }^{58}$ Bkz. el-Bakara 2/233, 286; el-En'âm 6/152; el-A'râf 7/42; en- Nahl 16/106; elMü'minûn 23/62.

${ }^{59}$ Buhârî, "Hudûd", 22, "Talâk", 11; İbn Mâce, "Talâk”, 15.

${ }^{60}$ Yiğit, İslam Ceza Hukuku Hükümlerinin Yürürlüğ̈̈, 35.

${ }^{61}$ el-Bakara $2 / 286$.

${ }^{62}$ Buhârî, "Talâk", 11, "Itk”, 6; Tirmizî, "Talâk”, 8; İbn Mâce, "Talâk”, 14-16; Nesâî, "Talâk", 22.

63 Buhârî, "Hudûd", 22; İbn Mâce, "Talâk", 15; Ebû Muhammed Abdullah b. Abdurrahmân ed-Dârimî, es-Sünen (İstanbul:Çağrı yayınları, 1992), "Hudûd", 1.

${ }^{64}$ Sulhi Dönmezer-Sahir Erman, Nazari ve Tatbiki Ceza Hukuku (İstanbul:1967), 2/158; Tesal, Ceza Hukuku, 33; Yaşar Yiğit, İslam Ceza Hukuku Hükümlerinin Yürürlüğ̈̈, (Ankara, Sistem Ofset, 2012), 34.

65 Önder, 267; Nevzat Toroslu, Ceza Hukuku (Ankara: 1991), 101; M. Cevat Akşit, İslam Ceza Hukuku ve İnsani Esaslarl (İstanbul: 1976), 46;Yiğit, İslam Ceza Hukuku Hükümlerinin Yürürlüğü, 34.

Turkish Academic Research Review - Türk Akademik Araştırmalar Dergisi https://dergipark.org.tr/tr/pub/tarr 
ve temyiz gücünün göz önünde bulundurulması, suçlarda manevi unsurun dikkate alınmasının tabii sonucudur. Dolayısıyla suçun oluşumu manevi unsurun varlığı ile mümkündür. Maddi unsurları tamam olan ancak manevi unsurları eksik kalan bir fiilin, suç teşkil etmesi ve cezalandırılması mümkün değildir. Nitekim gayri mümeyyiz çocuklar gibi temyiz gücüne sahip olmayan, akıl hastaları gibi irade ve temyizden yoksun insanlara veya ikrah altında kalarak suç işleyen şahıslara ceza uygulanmamasında temel etken, manevi unsurun bulunmamasıdır. ${ }^{66}$ Neticede cezaî sorumlulukta; failin ceza ehliyeti, fiilin hukuka aykırılığg, serbest irade ve kusurluluk belirleyici unsurlardır. ${ }^{67}$

Kur'ân-1 Kerim'de kişilerin sadece suç kastıyla işledikleri fillerinden sorumlu tutulabilecekleri, hata/taksir sonucunda meydana gelen fiillerden sorumlu tutulamayacakları ifade edilmektedir. “...Yanılarak yaptıklarınızda size vebal yoktur; fakat kalplerinizin bile bile yöneldiğinde günah vardır."68 buyurulmaktadır. Ayet, kişinin yanılarak, hata ile veya kasıtsız olarak işlediği yasak fiillerden dolayı vebalinin/sorumluluğunun bulunmadığını dile getirmektedir. Ancak ayet kişinin hata veya kasıtsız olarak işlediği yasak fiiller sebebiyle cezaî açıdan sorumlu tutulamayacağını vurgulamaktadır. Kişilerin hata yoluyla da olsa diğer şahısların mal veya canlarına verdikleri zararlarda, hukukî sorumlulukları devam etmektedir. Kusurlarının bulunması durumunda, meydana gelen zararı tazmin yükümlülükleri devreye girer. Çünkü şahısların tazminata konu olan haklarında, hata veya akıl hastaları, çocuklar gibi ceza ehliyetine sahip olmama hukuken bir mazeret olarak kabul edilmez. ${ }^{69}$ Ayrıca İslam hukukunda, "Zarar izale olunur." 70 genel kuralı da haksız fiillerin sonucunda ortaya çıkan zararların karşılanmasını gerekli kılmaktadır.

\section{Cezaî Sorumluluk Açısından İkrah ve Hukuki Sonuçları}

Konusu her ne olursa olsun şiddet, baskı ve tehditle başkasını rızasının olmadığı bir davranışta bulunmaya zorlamanın İslam dini açısından büyük günah olduğu, hukuki açıdan ise başkasının hürriyetine yönelik ağır suçlardan sayıldığı hususunda herhangi bir görüş ayrılığı söz konusu değildir. Gerek itikadî gerekse amelî bakımdan olsun kişilerin serbest irade ve seçimlerinin korunması, dinin temel ilkelerinden olduğundan herhangi bir kimseyi zorlama ve tehdide maruz birakmak,

${ }^{66}$ Yiğit, İslam Ceza Hukuku Hükümlerinin Yürürlüğü, 34.

${ }^{67}$ Bayar, İslam Hukukunda Ikrah, 21-22.

68 el-Ahzâb 33/5.

${ }^{69}$ Hafizüddin Nesefî, Keşfü'l-esrâr (İstanbul:1986), 2/306; Zeydân, el-Vecîz, s. 115.

${ }^{70}$ Mecelle, 20. madde. 
kul hakkı ihlali olup zorlayan açısından haram ve zulüm sayılan bir davranıştır. Bu şekilde elde edilen mal ve menfaat de gasp edilmiş mal hükmündedir. ${ }^{71}$

Daha önce de tanımlandığı şekliyle cezaî sorumluluk; bir şahsın, serbest irade ve doğuracağı sonuçları bilerek suç kastıyla işlemiş olduğu yasak/hukuka aykırı fiillerin neticesine katlanmasıdır. Bu itibarla cezaî sorumluluk, İslam ceza hukukundaki yaygın tasnifiyle hadler, cinayetler (öldürme ve yaralamalar) ve ta'zir şeklindeki üçlü ayırımda ${ }^{72}$ yer alan suçların işlenmesi karşıllı̆ında failin normda belirtilen ceza açısından sorumlu tutuluşunu ifade etmektedir. Bir başka ifade ile bu kapsamda yer alan suçlardan herhangi birinin işlenmesi durumunda gerekli diğer şartların da bulunmasıyla failin öngörülen cezaya çarptırılmasıdır. Söz gelimi hırsızlık suçu işleyen kimseye suçun diğer şartlarının da bulunmasıyla el kesme cezasının uygulanmas1, cezaî sorumluluğun bir gereği olarak gündeme gelmektedir.

Diğer taraftan cezaî sorumlulukta kişinin ehliyeti haiz olup olmaması ayrı bir önem arz etmektedir. Ehliyet, kişinin haklardan faydalanmaya, bahse konu hakları kullanmaya ve borçlanmaya elverişliliği demek olduğundan, cenin safhasından itibaren aklî ve fiziksel gelişim seyrine paralel olarak parça parça bu ehliyeti kazandığı ve rüssd ile bunun tamamlandığı görülür. ${ }^{73} \mathrm{Bu}$ bağlamda mükrehin ehliyeti açısından ikraha bakıldığında hangi türde olursa olsun zorlamanın vücûb/hak ehliyeti açısından olumsuz bir sonuç doğurmayacağı açıktır. Eda/Fiil ehliyeti açısından ise, İslâm hukukçuları, ikrahın kişinin fiil ehliyetini ve şer‘̂̀ teklife muhatap oluşunu ortadan kaldırmadığını ifade etmişlerdir. Nitekim Hanefîlerden Serahsî, ikrâhın tanımını yaparken onun rıza ve ihtiyâra etkisini vurgularken ehliyeti ortadan kaldırmadığına dikkat çekmiştir. ${ }^{74}$ Hanefîlerin ikrahı ehliyetten çok irade ile ilişkilendirmeleri, bu mezhepte ikrâhın hukuk alanında cezaî ehliyete etkisi açısından değil iradeye dayalı davranışlardan kaynaklanan cezaî ve medenî sorumluluklara etkisi açısından önemli görüldüğünü göstermektedir. Fakihler böyle bir kanaati dile getirirken, mükrehin her türlü fiilinden sorumlu olduğunu değil ikrah sonucu işlenen fiile vücûb, hurmet, ibâha gibi şer'î hitabın veya sıhhat ve fesad gibi hukuki bir sonucun terettüp ettiğini, ikrah sebebiyle hüküm ve hükmün nispet edileceği mahal değişse de sonucun ortadan kalkmadığını kastetmektedirler. ${ }^{75}$

\footnotetext{
${ }^{71}$ Bardakoğlu, "İkrah", 22/33.

${ }^{72}$ Bkz. Ûdeh, et-Teşrîu' l-cinâiyyü'l-ìslâmî, 1/58; Ebu Zehra, el-Cerîme, 61; A.Fethî Behnesî, Medhalu'l-fikhı 'l-İslâmî (Beyrut:Daru'ş-Şurûk, 1983), 30; Yiğit, İslam Ceza Hukuku Hükümlerinin Yürürlüğ̈̈, 37.

${ }^{73}$ Zeydân, el-Vecîz, 92; Bardakoğlu, "Ehliyet", 10/534.

${ }^{74}$ Serahsî, el-Mebsût, 24/38.

${ }^{75}$ Bardakoğlu, "İkrah", 22/33.
}

Turkish Academic Research Review - Türk Akademik Araştırmalar Dergisi https://dergipark.org.tr/tr/pub/tarr 
İkrahın etkisi, zor altında yapılan hukuki işlemin, suç veya günah teşkil eden fiilin özelliğine göre değişir ve kendisine hukuki sonuç bağlanır. İkrah altında gerçekleşen eylemin hem mükrih hem de mükreh açısından ortaya çıkan hukukî ve cezaî sorumluluğu söz konusudur. $\mathrm{Bu}$ itibarla mükrehin hukuka aykırı olarak gerçekleştirmiş olduğu bir eylemden dolayı sorumluluğu konusu iki açıdan ele alınabilir. Hukukî/Medenî sorumluluk bakımından kişinin bir başkasına yönelik haksız bir fiil ile zarar vermiş olması, tazmin yükümlülüğü için yeterli şarttır. Mükrehin ikrah altında diğer şahıslara vermiş olduğu zarar ile kendisi arasında bir illiyet bağı kurulursa tabii olarak tazmin sorumluluğu doğar. Tazmin sorumluluğunun temeli, kişilerin mal ve canlarının dokunulmazlığı ilkesine dayanmaktadır. Ayrıca faile ceza uygulanmaması için geçerli kabul edilen özürler, tazmin sorumluluğuna tesir etmez. ${ }^{76}$ Hukukî sorumluluğun konusu, itlaf edilen veya gasp edilen maddi varlığın misliyle ya da kıymetiyle tazminidir. Buradaki tazmin sorumluluğu, ikrahın ağırlığına göre mükrih ve mükrehe aittir. Bu itibarla İslam hukuk doktrininde malı tazmin edecek şahsın, zorlayan mı yoksa zorlanan mı olduğu konusu tartışılmıştır. Hanefîlere göre, tam ikrahta itlafa konu olan malı zorlayan tazmin etmek zorundadır. Eksik ikrahta ise, tazmin yükümlülüğü zorlanana aittir. ${ }^{77}$ Araştırma konumuzun dışında kalan mükrehin sözlü tasarrufları da İslam hukukçuları arasında tartışılmıştır. Fakihlerin çoğunluğu mührehin sözlü tasarruflarının herhangi bir hukuki sonuç doğurmadığına ilişkindir. Buna karşılık Hanefiler mükrehin sözlü tasarruflarının hukuki bağlamda sonuç doğuracağını belirtmişlerdir. ${ }^{78}$

İkrah, kişinin rıza ve iradesini etkilediğinden fiillerin kasıt ve niyete bağlı olmayan sonuçlarını kural olarak etkilemez. Söz gelimi ikrah sonucu emzirme tıpkı iradî emzirme gibi süt mahremiyeti doğurur. Zorlanan kimsenin zinasının sıhrî mahremiyet, adam öldürmesinin mirastan mahrumiyet sonucu doğurması ise fakihler arasında tartışmalı olup bu sonuçları fiile bağlayanlara göre durum yine aynıdır. Fiillerin irade ve kasta taalluk eden dinî ve hukukî sonuçlarına gelince, gayri mülcî ikrah sonucu yapılan işlerin sorumluluğu faile aittir. ${ }^{79}$

${ }^{76}$ Ebû Zehra, el-Cerîme, 430; Şamil Dağcı, İslam Ceza Hukukunda Şahıslara Karşı Müessir Fiiller (Ankara: Diyanet İşleri Başkanlığı Yayınları, 1996), 96.

${ }^{77}$ Kâsânî, Bedâiu's-sanâi', 7/179; Molla Hüsrev, Mir'âtu'l-usûl (Kahire: 1328), 328; Dâmâd, Mecmau'l-enhur, 2/433; Ûdeh, et-Teșrîu'l-cinâiyyü'l-İslâmî, 1/574.

78 İkrahın sözlü tasarruflara etkisi için bkz. Serahsî, el-Mebsût, 24/38; Kâsânî, Bedâiu's-sanâi', 7/182; Molla Hüsrev, Dureru'l-hukkâm, 2/271; İbn Âbidîn, Reddü'l-muhtâr, 9/179; Zuhaylî, el-Fıkhu'l-İslâmî ve edilletuhû, 5/403; Zeydân, elVecîz, 138; Karaman, İslam Hukuku, 2/155;Bardakoğlu, "İkrah", 22/33;Bayar, İslâm Hukukunda İkrâh ve Hukûkî Sonuçları, 188.

${ }^{79}$ Bardakoğlu, "İkrah”, 22/36. 
Şari`in/Hüküm koyucunun, ikrah hâlinde işlenmesine izin verdiği fiillerin icra edilmesi durumunda, mükrehin cezaî sorumluluğu yoktur. Bu kapsamda yer alan eylemler hayatın idamesi veya canın muhafazası söz konusu olduğunda zaruret kapsamında değerlendirildiğinden mubah hale gelmektedir. Bu itibarla can ve vücut tamlığına yönelik ikrah da bu kapsamda değerlendirildiğinden söz konusu hususların yapılması mubah hale gelir ve fail işlediği bu fiillerinden dolayı günahkâr olmadığı gibi cezaî açıdan da sorum tutulmaz. Küfrü gerektiren bir sözü söylemeye, ölü hayvan eti yemeye ya da içki içmeye zorlanan şahıs, bu fiilleri işlerse, cezaî sorumluluğu söz konusu değildir. Belirtilen durumlarda, zorlanana/mükrehe, ceza verilmeyeceğine, “Şüphesiz ki Allah, size leşi, kanı, domuz etini, bir de Allah’tan başkası adına kesilenleri haram kıldı. Bir kimse mecbur kalır, zaruret haddini aşmadan ve başkalarının hakkına tecavüz etmeden bunlardan yer ise, ona günah yoktur. Şüphesiz ki Allah, çok bağışlayan ve merhamet edendir." ümmetimden hata, unutma ve (istemedikleri hâlde) zor altında kalarak yaptıkları şeylerden ötürü (doğacak sorumlulukları) kaldırmıştır." "»1 hadisi delil teşkil etmektedir. Şu kadar var ki, bu gibi fiillerin serbest hâle gelebilmesi için zorlamanın tam/mülcî olması gerekli görülmüştür. Şayet zorlama tam olmazsa/gayr-i mülcî ikrah, mükrehin cezaî sorumluluğu devam eder. ${ }^{82}$ Fakat zaruret kapsamında da olsa başkasına verilen maddi zararlarda ikrahın ağırlığına göre zorlananın hukukî sorumluluğu devam eder. ${ }^{83}$

İslam hukukçuları, ikrah-1 mülcîin, öldürme, vücut bütünlüğüne yönelik yaralama veya kesme gibi müessir fiiller ya da kişinin ölümüne sebebiyet verecek derecede dövme suçlarında, zorlanan kişiden sorumluluğu kaldırmayacağı konusunda ittifak etmişlerdir. ${ }^{84} \mathrm{Bu}$ konuda “...Allah'ın haram kıldığı cana haksız yere

${ }^{80}$ el-Bakara 2/173.

${ }^{81}$ Buhârî, "Itk", 6, "Talâk”, 11; Ebû Dâvûd, "Talâk”, 15; Tirmizî, “Talâ"k, 8; Nesâî, "Talâk", 22; İbn Mâce, "Talâk", 14, 16.

82 Kâsânî, Bedâiu's-sanâi', 7/176; Molla Hüsrev, Dureru'l-hukkâm, 2/270; Dâmâd, Mecmeu'l-enhur, 2/432; Ûdeh, et-Teşrîu'l-cinâiyyü'l-İslâmî, 1/570; Zuhaylî, V, 391.

${ }^{83}$ Serahsî, el-Mebsût, 24/48; Kâsânî, Bedâiu's-sanâi', 7/176; İbn Kudâme, el-Muğnî, 10/330; Hattâb, Mevâhibu'l-celîl, 3/229; Dâmâd, Mecma', 2/432; Ûdeh, et-Teşrîu'lcinâiyyü'l-İslâmî , 1/570; Zeydân, el-Vecîz, 141; Cubûrî, Avarızu'l-ehliyye, 517; İsmail Acar, "Hanefi Fıkhında Mükrehin Cezaî Sorumluluğu”, Dokuz Eylül Üniversitesi Illahiyat $\quad$ Fakültesi Dergisi 42 (İzmir 2015), 17.

${ }^{84}$ Serahsî, el-Mebsût, 24/67; Kâsânî, Bedâiu's-sanâi', 7/177; İbn Âbidîn, Reddu'lmuhtâr, 9/187; Molla Hüsrev, Dureru'l-hukkâm 2/271; Mansûr b. Yunus b. İdrîs elBuhûtî, Keşşâfu'l-kina' an metni'l-Ikna' (Beyrût:1982), 5/601; Dâmâd, Mecmeu'lenhur, 2/433; Bilmen, Istılahatı Fıkhiyye Kamusu, 3/73; Cubûrî, Avarızu'l-ehliyye, 514, Zuhaylî, el-Fıkhu'l-íslâmî , 5/399.

Turkish Academic Research Review - Türk Akademik Araştırmalar Dergisi 
kıymayın..."85 ayeti, İslam hukukçularının başlıca delillerinden birisini teşkil etmektedir. Zorlanan kişinin bu tür eylemlerinden dolayı cezaî sorumluluğu, kendisini zorlayandan/mükrihten kurtarmak için mağduru kasten öldürmesi gerekçesine dayanmaktadır. ${ }^{86}$

Zorlanan kişinin, tam ikrah altında işlemiş olduğu öldürme ve müessir fiillerde cezalandırılacağı hususunda aynı görüşü paylaşan hukukçular, verilecek cezanın kısas, diyet ve ta'zir türünden hangisi olacağı konusunda ise, farklı görüşler ileri sürmüşlerdir. Burada mükrehin cezaî sorumluluğunun bütün unsurlarıyla teşekkül ettiği kanaatini taşıyan fakihler haliyle kısasa hükmedecektir. Buna karşılık suç kastının bütün unsurlarıyla teşekkül etmediği görüşünde olan hukukçular da eylemi taksirle işlenmiş suç kapsamında değerlendirerek hukukî sorumluluk bağlamında diyete hükmedeceklerdir. Mükrehin cezaî sorumluluğunun ne kısas ne de tazmin sorumluluğuna kifayet etmeyeceği görüşünde olan fakihler ise, yasak bir fiilin işlenmesinden dolayı ta 'zir kapsamında değerlendirilen bir cezaya hükmedeceklerdir. Nitekim Mâlikî ve Hanbelîlere göre zorlanan kişi, işlemiş olduğu öldürme ve müessir fiillerinden dolayı kısas cezasına çarptırılır. ${ }^{87}$ Şâfiî mezhebindeki hâkim görüşe göre de zorlanana kısas cezası uygulanır. ${ }^{88}$ Hanefîlerde ise, bu durumda uygulanacak ceza konusu, mezhep hukukçuları arasında tartışılmıştır. Ebû Hanîfe ve İmam Muhammed'e göre zorlanan/mükreh, yetkili merciin uygun göreceği ta'zir türünden bir cezayla cezalandırılır. Zorlayana ise, kısas cezası uygulanır. Ebû Yûsuf' a göre ise, zorlanan diyet ödemekle yükümlü tutulur. İmam Züfer de zorlanana kısas cezası uygulanacağını ifade etmiştir. ${ }^{89}$ Belirtilen bu görüşlerinden ortaya şu sonuç çıkmaktadır: Çoğunluk İslam hukukçularına göre, bir şahıs tehdidin ağırlığı ve derecesi ne olursa olsun, kendisini kurtarmak için diğer şahsa karşı öldürme, yaralama ve kesme gibi ağır müessir fiilleri hiçbir surette işleyemez. Şayet ağır ikrah altında da

85 el-En'âm 6/151.

86 Serahsî, el-Mebsût, 24/45; Kâsânî, Bedâiu's-sanâi', 7/177; Şîrâzî, el-Mühezzeb, 2/177; Molla Hüsrev, Dureru'l-hukkâm, 2/271.

${ }^{87}$ Ebû'l-Velid Muhammed b. Ahmed İbn Rüşd, Bidayetü'l-müctehid ve nihayetü'lmuktesıd (İstanbul: 1985), 2/331;Buhûtî, Keşşâfu'l-kına', 5/603; Hattâb, Mevâhibu'l-celîl, 6/242; İbn Kudâme, el-Mugnî, 9/331; Şerefuddîn Mûsa elMakdisî el-Haccâvî, el-Iknâ' li tâlibi'l-intifâ' (Kahire:1351), 4/171; Ûdeh, etTeşrîu'l-cinâiyyü'l-İslâmî, 1/569; Zeydân, el-Vecîz, s. 142; Zuhaylî, el-Fıkhu'lİslâmî, 5/399.

${ }^{88}$ Şîrâzî, el-Mühezzeb, 2/177; Şihâbuddîn Ahmed b. Haceri el-Heytemî, Tuhfetu'lmuhtâc bi şerhı'l-Minhâc (Mısır: 1328), 4/7; Kâsânî, Bedâiu's-sanâi', 7/179; Ûdeh, et-Teşrîu'l-cinâiyyü'l-İslâmî, 1/570.

${ }^{89}$ Kâsânî, Bedâiu's-sanâi', 7/179; İbn Âbidîn, Reddü'l-muhtâr, 9/187; Moll Hüsrev, Dureru'l-hukkâm, 2/271; Ûdeh, et-Teşrîu'l-cinâiyyü'l-İslâmî, 1/569; Zeydân, elVecîz, s. 142; Zuhaylî, el-Fıkhu'l-İslâmî, 5/399. 
olsa bu suçların işlenmesi durumunda, fail fiillerinin sonuçlarından cezaî bakımdan

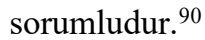

Kanaatimize göre, tam zorlama altında öldürme suçu işleyen şahsa kısas cezasının uygulanması gerektiği görüşü, suçun oluşum süreçleri, genel unsurları ve adalet ilkesi açısından isabetli gözükmemektedir. Zira ikrah altındaki kişinin, cezaî sorumluluğun temel unsurlarından olan serbest irade ve suç kastının varlığından söz etme imkânımız yoktur. Serbest irade ve suç kastının bulunmadığı veya tam oluşmadığı durumlarda işlenen suça karşılık aslî cezanın uygulanması, hukuk normları ve cezalandırma amaçları açısından isabetli değildir. Diğer taraftan ikrahın, mükrehin rızasını yok ettiği konusunda İslam hukukçuları arasında görüş birliği vardır. Hanefiler dışındaki fukaha, ikrahın ihtiyarı da ortadan kaldırdığını ifade etmektedirler. Buradan hareketle ikrahın hem rıza hem de ihtiyarı ortadan kaldırdığı görüşünde olup akabinde mükrehin cezaî sorumluluğunun devam ettiğini benimsemek çelişkiyi beraberinde getirecektir. Zira mükrehin hem serbest iradesi yoktur hem de suça rızasından söz edilemez. Dolayısıyla suç kastının varlığından söz edemediğimiz bir kimseye işlenen suçun aslî cezasını öngörmek adalet ilkesi ve hukuk normlarına aykırıdır. Bu itibarla mükrehin cezaî sorumluluğunun olmadığı kanaatinde olan Ebû Hanîfe ve İmam Muhammed'in görüşlerinin, hukuk normları ve tekniği açısından tercihe daha uygun olduğunu ifade edebiliriz. Buna ilaveten yetkili merci, zorlanan ve suça zorlayan şahısların durumlarını tetkik ettikten sonra mükrehe ta'zir kapsamında değerlendirilebilecek türden bir ceza ya da yaptırım uygulayabilir.

İkrah altında bir başkasına zina iftirasında bulunan, hırsızlık yapan ve başkasının malını itlaf eden mükrehe cezaî sorumluluğu bulunmadığından dolayı işlenen suçlar için öngörülen cezalar uygulanmaz. ${ }^{91}$ Ancak belirttiğimiz suçlarda, zorlanan kişinin her ne kadar cezaî sorumluluğu söz konusu olmasa da ikrahın derecesine göre hukuki sorumluluğu devam ettiğinden, fiilleri sonucunda meydana gelen zararları tazmin etmekle yükümlüdür. Burada tazmin yükümlülüğü ikrahın ağırlığına göre ya mükrihe ya da mükrehe aittir.

Zinaya zorlanan kadına, bu fiili işlemesi durumunda ceza uygulanmayacağ 1 konusunda İslam hukukçuları görüş birliği içindedirler..$^{92}$ Yine fakihlerin çoğunluğu,

90 Serahsî, el-Mebsût, 24/47; Molla Hüsrev, Dureru'l-hukkâm, 2/271; Şîrâzî, elMühezzeb, 2/177; Buhûtî, Keşşâfu'l-kınâ', 5/601; Bilmen, Istılahatı Frkhiyye Kamusu, 3/72; Ûdeh, et-Teşrîu' 'l-cinâiyyü'l-İslâmî, 1/569.

${ }^{91}$ Serahsî, el-Mebsût, 24/77; Kâsânî, Bedâiu's-sanâi', 7/187; Şemsüddin Muhammed b. Ahmed er-Remlî, Nihâyetü'l-muhtâc ilâ şerhi'l-Minhâc (Beyrut: Daru'l-Kütübi'l-i̇lmiyye, 2003), 7/415;Hattâb, Mevâhibu'l-celîl, 5/294.

92 Kâsânî, Bedâiu's-sanâi', 7/181; Şîrâzî, el-Mühezzeb, 2/267; Molla Hüsrev, Dureru'l-hukkâm, 2/271; İbn Kudâme, el-Mugnî, 10/158; Haskefî, ed-Durru’l-

Turkish Academic Research Review - Türk Akademik Araştırmalar Dergisi 
zorlama ve tehdit altında zina suçu işleyen erkeğe de ceza uygulanmayacağını ifade etmişlerdir. ${ }^{93}$ Buna karşılık Ebû Hanîfe'den, zor altında zina fiili işleyen erkeğe zina haddi uygulanacağı şeklinde bir görüş nakledilmiştir. Ancak Ebû Hanîfe'nin daha sonra bu görüşünün çerçevesini daralttığı ve ikrahın yetkili merci tarafından yapılması durumunda, mükrehe zina haddi (recm veya celde) uygulanmayacağı bunun dışındaki zorlamalarda ise, mükrehe ceza uygulanacağını belirttiği nakledilmiştir. ${ }^{94}$

Kanaatimizce çoğunluğun görüşü gerek deliller gerekse nassların maksat ve ruhu açısından daha isabetli gözükmektedir. Zor altında zina suçu işleyen ister erkek olsun ister kadın ya da zorlamanın kaynağı ister yetkili merci olsun ister yetkisiz şahıs, mükreh konumundaki kişiye ceza uygulanmamalıdır. Çünkü işlenen herhangi bir suçta kişilere ceza uygulanabilmesinde, serbest irade ve suç kastı en önemli unsur ve de etkendir. Buna göre, zor ve tehdit altında zina fiilini işlemiş kadın ya da erkeğin, suç kastının varlığından söz etmek imkânı yoktur. Diğer taraftan zor altında zina suçu işleyen kadına ceza uygulanmazken aynı şartlar altında suç işleyen erkeğe ceza uygulanmasının adalet ve hakkaniyet ilkeleri açısından da isabetli olduğunu ifade etmek zordur. Zira suç kastının varlığı ya da yokluğu, cinsiyete göre değişkenlik arz edecek nitelikte bir olgu değildir. Ayrıca Peygamber'in (s.a.s.), “Şüphesiz Allah, ümmetimden hata, unutma ve (istemedikleri hâlde) zor altında kalarak yaptıkları şeylerden ötürü (doğacak sorumlulukları) kaldırmıştır." ${ }^{95}$ hadisi de böyle bir kanaate ulaşılmasında yeterli delildir. Bu hadis, zor altında kalan kişiyi, kadın-erkek şeklinde bir ayrıma tâbi tutmamaktadır. Gerek İslam hukukunda gerekse günümüz ceza hukukunda, bir kişinin işlemiş olduğu suç sebebiyle cezaî sorumluluğu için serbest irade, temyiz gücü ve kusurunun bulunması gerekli unsurlardır.

Netice itibariyle ikrah, her iki çeşidiyle mükrehin rızasını yok etmektedir. Rızanın yok olduğu bir vasatta, kişinin serbest iradesinden ve ortaya çıkan sonucu arzuladığına ilişkin kastından söz etmek mümkün değildir. Cezaî sorumlulukta, kişinin özgür iradesi, temyiz gücü ve kusurluluk/suç kastı olmazsa olmazlardandır. Dolayısıyla kişilerin can, mal ve vücut tamlığına yönelik ikrah altında bir eylemde

muhtâr, 9/188; Udeh, et-Teşrîu'l-cinâiyyü'l-İslâmî, 1/573; Bilmen, Istılahatı Fıkhiyye Kamusu, 3/209; Zuhaylî, el-Fıkhu'l-İslâmî, 5/400.

93 Kâsânî, Bedâiu's-sanâi', 7/180; İbn Kudâme, el-Mugnî, 10/159; Heytemî, Tuhfetu'l-muhtâc, 4/91; Hattâb, Mevâhibu'l-celîl, 5/294; Ûdeh, et-Teşrîu'lcinâiyyü'l-İslâmî, 1/573; Cubûrî, Avârızu'l-ehliyye, 518.

${ }^{94}$ Kâsânî, Bedâiu's-sanâi', 7/180; Haskefî, ed-Durru'l-muhtâr, 9/188; İbn Kudâme, el-Muğnî, X, 159; Ûdeh, et-Teşrîu'l-cinâiyyü'l-İslâmî, 1/573; Bilmen, Istılahatı Flkhiyye Kamusu, 3/209; Zuhaylî, el-Fıkhu'l-İslâmî, 5/401; Cebbûrî, Avârızu'lehliyye, 500.

${ }^{95}$ Buhârî, "Itk", 6, "Talâk", 11; Ebû Dâvûd, "Talâk", 15; Tirmizî, "Talâk”, 8; Nesâî, "Talâk”, 22; İbn Mâce, "Talâk”, 14, 16. 
bulunan kişinin cezaî sorumluluğunun tam olarak teşekkül ettiğinden söz etmek mümkün değildir. Tabii ikrahın tam ikrah kapsamında değerlendirilmesi sorumluluğun derecesinin tespitinde ayrı bir önem arz etmektedir. İkraha konu olan eylem, ikrah sonucunda ortaya çıkacak eylemden daha hafif ise, böyle durumda mükrehin cezaî sorumluluğunun bulunmadığından söz edemeyiz. Söz gelimi, miktarı her ne olursa olsun, mal itlafı veya dövülmekle tehdit edilen kimsenin bir başkasının can ve vücut tamlığına yönelik işlemiş olduğu suçlarda cezaî sorumluluğu devam eder. Şu kadar var ki, öldürme ve yaralama gibi eylemlerde, mükrehe her ne kadar asli ceza uygulanmazsa da söz konusu durum bu tür eylemleri günah olmaktan asla çıkarmaz. Kısaca ifade etmek gerekirse, had, cinayet ve ta'zir kapsamında ele alınan suçların tam ikrah altında işlenmesi durumunda mükrehin cezaî sorumluluğu söz konusu değildir. İkrah-1 gayrı mülcî ise, öldürme ve yaralama suçlarında failin cezaî sorumluluğuna etki etmez. Nitekim İslam hukuk literatüründe önemli bir yere sahip olan Bedâiu‘s-sanâi‘ müellifi Kâsânî (ö:587/1191), ikrahın hukuki sonuçlarını üç başlık halinde özetlemiştir:

a) Haram veya yasaklı̆̆ının zaruret ölçüsünde düştüğü durumlarda, ikrah altında yapılması istenen fiilin yerine getirilmesi mubahtır. Burada Şari'in izin verdiği ölçüde mubah olanın mükreh tarafindan yerine getirilmesi gerekir, terki sorumluluk doğurur.

b) Eylem veya davranışın haramlığı devam etmekle beraber, baskı ve tehdit altında yapilması veya terkedilmesine izin verilen durumlar. Bu halde ruhsatın kullanılması veya kullanılmaması tehdit altındaki kişinin tercihine bırakılmıştır. Mükrehin karşı karşıya kaldığı her iki halden birini tercihi de caizdir.

c) Yapılmasına hiçbir şekilde izin verilmeyen, mubahlığın söz konusu olmadığı ve haramlığın devam ettiği durumlar. Bu kapsamda söz konusu olan fiil veya terkin, ikrah altında yerine getirilmesi durumunda mükreh ahirette günah, dünyada ise ortaya çıkan zararı tazminle karşılaşır. ${ }^{96}$

\section{Sonuç}

Şiddet, baskı ve tehditle başkasını rızasının olmadığı bir davranışta bulunmaya zorlamanın İslam dini açısından büyük günah olduğu, hukuki açıdan ise, başkasının hürriyetine yönelik ağır suçlardan sayıldığı hususunda fakihler arasında görüş ayrılığı söz konusu değildir. Gerek itikadî gerekse amelî bakımdan kişilerin serbest irade ve seçimlerinin korunması, dinin temel prensiplerinden olduğundan

${ }^{96}$ Kâsânî, Bedâiu's-sanâi', 7/176.

Turkish Academic Research Review - Türk Akademik Araştırmalar Dergisi https://dergipark.org.tr/tr/pub/tarr 
herhangi bir kimseyi zorlama ve tehdide maruz bırakmak, zorlayan açısından haram ve zulüm sayılan bir davranıştır. Diğer taraftan bahse konu tehdit ve zorlama kul hakkı ihlâli olup büyük günahtır.

İnsanın, eylem, söz ve davranışlarının iradesi doğrultusunda gerçekleşip gerçekleşmemesinin hukuki açıdan önemli sonuçları vardır. Bahse konu sonuçlara, hukuki bağlamda hüküm isnadında ve kişinin sorumluluğunun tespitinde, serbest irade yadsınamaz bir konumu haizdir. İrade ise, öz itibariyle rıza ve ihtiyardan oluşan iki temel unsurdan teşekkül eder. İhtiyar, bir şeyi yapıp yapmama hususunda kişinin tercihte bulunmasını, rıza ise bir şeyi arzu edip etmemede gönül hoşluğu ve memnuniyeti ifade etmektedir. Bu itibarla kişinin hiçbir etki ve baskı altında kalmadan, kendi rızası ve tercihiyle yaptığı fiillerden ve söylediği sözlerden sorumlu tutulması oldukça doğaldır. Zira bunlar kendi serbest iradesinin bir sonucudur. Ancak bazen kişinin iradesini sakatlayan, rızasını yok eden durumlar söz konusu olabilmektedir. İkrah hali de bunlardan birisidir.

İkrah; tehdit ettiği şeyi yapmaya güç yetirebilecek potansiyele sahip bir şahsın, bir başka kişiyi, korkutmak ya da tehdit suretiyle kendi hâline bırakıldığında yapmaya rıza göstermeyeceği ve tercih etmeyeceği bir fiili işlemeye ya da bir sözü söylemeye sevk edilmesidir. İkrah, tehdidin konusuna ve ağırlığına göre tam/mülcî ve eksik/gayr-i mülcî şeklinde ikili bir ayrıma tabi tutulmaktadır.

İkrah, İslam hukukunda ehliyet arızaları kapsamında ele alınmakla beraber çağdaş İslam hukukçularının kaleme aldıkları eserlerde rızayı bozan sebepler veya irade sakatlıkları bağlamında değerlendirilen bir durumdur. İslam hukukçuları, mükrehin söz ve fiillerinin hukuki sonuçlarına ilişkin farklı değerlendirilmelerde bulunmakla birlikte hemen hepsi ikrahın rızayı ortadan kaldırdığı hususunda hemfikirdirler. Hanefiler diğer fukahadan farklı olarak ister tam ikrah olsun ister eksik ikrah olsun her iki çeşidiyle ikrahın rızayı ortadan kaldırdığını buna karşın ihtiyarın gayr-i mülcî/eksik ikrahta bozulmadığını, mülcî/tam ikrahta ise bozulmakla beraber ortadan kalkmadığını belirtmişlerdir. Hanefiler, ikrahın ihtiyarı bozmakla beraber ortadan kaldırmadığı dolayısıyla mükrehin bu kapsamdaki tasarruflarının hukuki sonuç doğurduğu kanaatini taşımaktadırlar.

İkrah, zorlananın rızasını kaldırdığına göre ilkesel olarak mükrehin cezâ̂ sorumluluğundan söz etmek mümkün değildir. Zira cezaî sorumlulukta fiilin hukuka aykırılığı yanında serbest irade, temyiz gücü ve kasıt temel unsurlardır. Bu unsurların ikrah altında varlığından söz edemeyeceğimizden ister had, ister cinayet, ister ta'zir kapsamında olsun işlenen suçtan dolayı mükrehin cezaî sorumluluğundan bahsedilemez. Zira mükrehin ortaya çıkan sonuca ilişkin kasta yönelik rızası ve iradesi yoktur. Diğer taraftan ikrahın ağırlığı, gerçekleşme olasılığı ve şartları bu 
sorumluluğun tespitinde önemli etkendir. İkrahın cezaî sorumluluğa etkisinin belirlenmesinde zararın aynı büyüklükteki başka bir zarar ile ortadan kaldırılamayacağı ilkesi ile şiddetli zararın hafif zarara katlanılarak ortadan kaldırılacağı kuralı etkili olmuştur. Bu itibarla mükrehin daha az bir zarara karşı1ık daha çok bir zararı tercihi durumunda kendisi de cezaî açıdan sorumlu olacaktır. Dolayısıyla ikrahı gayr-i mülcî kapsamında değerlendirilen bir zorlama ile mükrehin, can, mal ve vücut tamlığına karşı işleyeceği suçta cezaî sorumluluğu devam edecektir.

İkrah altında kalan kimsenin, Şari' in zaruret halinde işlenmesine izin verdiği sözleri söylemesi ve eylemleri yapması durumunda cezaî sorumluluğu söz konusu değildir. Zira bu tür eylemlerde suç kastının yanı sıra hukuka aykırılık unsuru da ortadan kalkmış olmaktadır. Mükreh, bu tür eylemlerinden dolayı günahkâr da olmaz. Şu kadar var ki, bu kapsamdaki söz veya fiillerin suç olma niteliği devam etmektedir.

Mükrehin sözlü tasarrufları da İslam hukukçuları arasında tartışılmıştır. Şafiî, Maliki ve Hanbelî hukukçularına göre zorlananın sözünün hukuki hiçbir değeri yoktur. İkrah altında iken zorlananın sarf edeceği sözler, kendisini bağlamamaktadır. Zorlananın boşaması, satım akdi yapması ve sözlü tasarrufları geçersizdir. Buna karşılık Hanefiler mükrehin sözlü tasarruflarının hukuki bağlamda sonuç doğuracağını belirtmişlerdir.

Etik Beyan / Ethical Statement Bu çalışmanın hazırlanma sürecinde bilimsel ve etik ilkelere uyulduğu ve yararlanılan tüm çalışmaların kaynakçada belirtildiği beyan olunur/It is declared that scientific and ethical principles have been followed while carrying out and writing this study and that all the sources used have been properly cited. Yazar / Author Yaşar Yiğit

\section{Kaynakça}

Acar, Halil İbrahim. "İslâm Borçlar Hukukunda İradeyi Sakatlayan Sebepler IIİkrah". Atatürk Üniversitesi İlahiyat Fakültesi Dergisi 18 (Erzurum 2002), 19-38. Acar, İsmail. "Hanefi Fikhında Mükrehin Cezaî Sorumluluğu". Dokuz Eylül Üniversitesi Illahiyat $\quad$ Fakültesi Dergisi 42 (İzmir 2015), 9-41.

Akşit, M. Cevat. İslam Ceza Hukuku ve İnsani Esasları. İstanbul: 1976.

Âmir, Abdülaziz. Şerhu'l-ahkâmi'l âmme li'l cerîme. Bingazi: Câmiatü Karyûnus,1987.

Atar, Fahrettin. Fıkıh Usûlü. İstanbul: Marmara Üniv. İlahiyat Fakültesi Vakfı Yayınları, 1988.

Turkish Academic Research Review - Türk Akademik Araştırmalar Dergisi https://dergipark.org.tr/tr/pub/tarr 
Aydın, Hakkı. "İslam ve Türk Borçlar Hukukunda İkrah". Atatürk Üniversitesi Ilahiyat Fakültesi Dergisi 11 (1993), 299-325.

Bardakoğlu, Ali. "İkrah”, Türkiye Diyanet Vakfi İslâm Ansiklopedisi. 22/30-37. İstanbul: TDV Yayınları, 2000.

Bardakoğlu, Ali. "Ehliyet”, Türkiye Diyanet Vakfi İslâm Ansiklopedisi. 10/533-539. İstanbul: TDV Yayınları, 1994.

Bayar, Mesut. İslâm Hukukunda İkrâh ve Hukûkî Sonuçları. Ankara: Basılmamış Doktora Tezi, 2012.

Behnesî, A. Fethî. Medhalu'l-fikhı 'l-İslâmî. Beyrut: Daru'ş-Şurûk, 1983.

Behnesî, A. Fethî Medhalu'l-fikhı 'l-íslâmî. Beyrut: Daru'ş-Şurûk, 1983.

Behnesî, A. Fethî. el-Mevsûatü'l-cinâiyye fi'l-fikhi 'l-İslâmî. Beyrût:1991.

Beydâvî, Abdullāh b. Ömer b. Muhammed. Envâru't-Tenzîl ve esrâru't-te'vîl. Beyrut: Daru'l-Fikr, 2001.

Bilgili, İsmail. "Ehliyet Arızalarından İkrah Şartları ve Kısımları" İstanbul Üniversitesi Illahiyat $\quad$ Fakültesi Dergisi 1/1 (Bahar 2010), 237-270.

Bilmen, Ö. Nasûhi. Hukûkı İslâmiyye ve Istılahatı Fıkhıyye Kamusu. İstanbul: Bilmen Yayınevi, 1985.

Buhârî, Muhammed b. İsmail. el-Câmi 'u 's-sahîh. İstanbul: Çağrı Yayınları, 1992.

Buhârî, Alâuddîn Abdülazîz b. Ahmed. Keş̧fu'l-esrâr fì şerhi usûli'l-Pezdevî. İstanbul: $\quad 1308$.

Cubûrî, Hüseyin Halef. Avarizu'l-ehliyye inde'l-usûliyyîn. Mekke: 1988.

Dağcı, Şamil. İslam Ceza Hukukunda Şahıslara Karşı Müessir Fiiller. Ankara: Diyanet İşleri Başkanlığı Yayınları, 1996.

Dâmâd, Abdurrahman b. Muhammed b. Süleyman. Mecmau 'l-enhur. İstanbul: 1276. Dârimî, Ebû Muhammed Abdullah b. Abdurrahmân. es-Sünen. İstanbul: Çağrı yayınları, 1992.

Dönmezer, Sulhi - Erman, Sahir. Nazari ve Tatbiki Ceza Hukuku.İstanbul:1967.

Dümeynî, Misfir Gurmullah. el-Cinâye beyne'l fikhı'l-İslâmî ve'l-kânûni'l-vad'î. Cidde: ts.

Ebû Dâvûd, Süleyman b. Eş'as es-Sicistânî. es-Sünen. İstanbul: Çağrı Yayınları, 1992.

Ebû Zehra, Muhammed. el-Cerîme ve'l-ukûbe fi 'l-fikhl'l-íslâmî (el-Cerîme). Kahire: ts.

Ehdel, Hasen Muhammed Makbûlî. Usûlu'l-fikhı'l-ìslâmî. San'a: 1990.

Ensâri, Ebû Yahya Zekeriyya b. Muhammed. Esne'l-metâlib şerhu Ravzati'ttâlib.by.:ts.

Haccâvî, Şerefuddîn Mûsa el-Makdisî. el-Iknâ' li tâlibi'l-intifâ'. Kahire:1351. 
Haskefî, Alauddîn Muhammed b. Ali el-Hısnî. ed-Durru'l-muhtâr (Reddu'lMuhtâr'la). Beyrût:1994.

Hattâb, Ebû Abdullah Muhammed el-Mağribî. Mevâhibu'l-celîl li şerhı Muhtasari Halîl. Beyrût:1992.

Heytemî, Şihâbuddîn Ahmed b. Haceri. Tuhfetu'l-muhtâc bi şerhi'l-Minhâc. Misır: 1328.

İbn Âbidîn, Muhammed Emin b. Ömer. Reddü'l-muhtâr ala'd-Dürri'l-muhtâr. thk. Âdil Ahmed Abdülmevcûd-Ali Muhammed Muavvaz. Beyrût: 1994.

İbn Âbidîn, Muhammed Emin b. Ömer. Hâşiyetü Nesemâti'l-eshâr. Mısır: 1979.

İbn Kudâme, Ebû Muhammed Abdullah b. Ahmed. el-Muğnî. Beyrut: Dâru'lKütübi'l- İlmiyye, ts.

İbn Mâce, Ebû Abdullah Muhammed b. Yezîd. es-Sünen. İstanbul: Çağrı Yayınları, 1992.

İbn Manzûr, Ebu'l Fazl Cemalüddin Muhammed İbn Mükerrem. Lisânü'l-Arab. Beyrut: Dar-u Sâdır, ts.

İbn Melek, İzzuddin Abdüllatîf b. Abdülaziz. Şerhu'l-Menâr fi'l-usûl. İstanbul: ts. İbn Nüceym, Zeynüddin b. İbrahim b. Muhammed. el-Bahru'r-râik şerhu Kenzi'ddekâik. Beyrût:ts.

İbn Rüşd, Ebû'l-Velid Muhammed b. Ahmed. Bidayetü'l-müctehid ve nihayetü'lmuktesid. İstanbul: 1985.

İnan, A.Naim. Borçlar Hukuku. Ankara: 1973.

Karaman, Hayreddin. Mukayeseli İslam Hukuku. İstanbul: Nesil Yayınları,1987.

Kâsânî, Alâuddîn Ebû Bekr b. Mes'ûd. Bedâiu's-Sanâi' fî tertîbi'ş-şerâi'. Beyrût: Daru'l-Kütübü'l- İlmiyye, 1986.

Köse, Saffet. “İslam Hukukunda İkrahın Sözlü Tasarruflara Tesiri”. Diyanet İlmi Dergi 32/2 (Ankara 1996), 35-53.

Kurtubî, Ebû Abdillah Muhammed b. Ahmed. el-Câmi‘ li ahkâmi'l-Kur'ân. Beyrut: Risale, 2017.

Molla Fenarî, Şemsüddin Mehmed b. Hamza. Fusûlu’l-bedâyi'. İstanbul: 1289.

Molla Hüsrev, Muhammed b. Ferâmuz . Dureru'l-hukkâm fì şerhi gureri'l-ahkâm. İstanbul: 1319.

Nesâî, Ahmed b. Şuayb, es-Sünen. İstanbul: Çağrı Yayınları, 1992.

Nevevî, Ebû Zekeriyyâ Yahya b. Şeref. Muğni'l-muhtâc. Beyrut: ts.

Nesefî, Hafizüddin. Keşfü'l-esrâr. İstanbul: 1986.

Önder, Ayhan Ceza Hukuku Dersleri. İstanbul: 1992.

Turkish Academic Research Review - Türk Akademik Araştırmalar Dergisi https://dergipark.org.tr/tr/pub/tarr 
Özkul, Burcu- Çarıkçı, İlker H. "Mobbing ve Türk Hukuku Açısından Değerlendirilmesi”. Süleyman Demirel Üniversitesi İktisadi ve İdari Bilimler Fakültesi Dergisi. 15/1 (Isparta 2010), 483-499.

Râzî, Fahruddin Muhammed b. Ömer. et-Tefsîru'l-kebîr. Beyrut: 2005.

Remlî, Şemsüddin Muhammed b. Ahmed. Nihâyetü'l-muhtâc ilâ şerhi'l-Minhâc. Beyrut: Daru'l-Kütübi'l-İlmiyye, 2003.

Senhûrî, Abdürrezzâk Ahmed. Masâdirü'l-hakkfi'l-fikhı'l-íslâmî. Beyrût:1953.

Serahsî, Şemsü'l-Eimme Muhammed b. Ahmed. Kitâbü'l-mebsût. Beyrût: Darü'lMarife, 1978.

Şîrâzî, Ebû İshak İbrahim b. Ali. el-Mühezzeb. Beyrut: Dârü’l-Fikr, ts.

Taner, Tahir. Ceza Hukuku. İstanbul: 1949.

Tesal, Reşat Dursun. Ceza Hukuku (İstanbul: 1979.

Timurtâşi, Şemsuddîn Muhammed b. Abdillâh. Tenvîru'l-ebsâr ve câmiu'l-bihâr (Reddu'l-Muhtâr'la). Beyrût 1994.

Tirmizî, Muhammed b. Îsa. es-Sünen. İstanbul: Çağrı Yayınları, 1992.

Toroslu, Nevzat. Ceza Hukuku. Ankara: 1991.

Yerlikaya, Ünal. "Hanefî Borçlar Hukuku Literatüründe Teaddî Kavramının Anlam Çerçevesi: Teaddî-Hukuka Aykırılık-Kusur İlişkisi Bağlamında Bir İnceleme”. Diyanet İlmi Dergi. 53/3. (Ankara 2017), 25-51.

Yıldız, Kemal. "Sorumluluk", Türkiye Diyanet Vakfi İslâm Ansiklopedisi. 37/380382. İstanbul: TDV Yayınları, 2009.

Yiğit, Yaşar. İslam Ceza Hukuku Hükümlerinin Yürürlügüu. Ankara, Sistem Ofset, 2012.

Ûdeh, Abdülkadir. et-Teşrîu'l-cinâiyyü'l-İslâmî mukârenen bi’l-kânûni'lvad'î. Beyrût: ts.

Zemahşerî, Mahmud b. Ömer. el-Keşşâf an hakâikl't-tenzîl ve uyûnu'l-akâvîl fî̀ vucûhı't-te'vil. Kahire: ts.

Zerkâ, Mustafa Ahmed. el-Medhalu'l-fikhi'l-âmm. Dımeşk: Dârü'l-Kalem, 1988.

Zeydân, A.Kerîm. el-Vecîz fì usûli'l-fikh. Beyrût: Mektebetu'l-Kuds, 1987.

Zuhaylî, Vehbe. el-Fılkhu'l-İslâmî ve edilletuhû. Dımeşk: 1989.

Zuhaylî, Vehbe. Nazariyyetü'd-damân ev ahkâmü'l-mesûliyyeti'l-Medeniyye ve'lcinâiyye fi'l-fikhı'l-İslâmî. Dımeşk: 1982. 